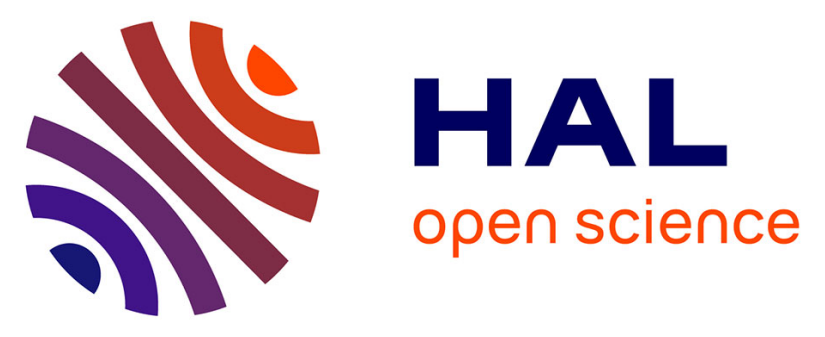

\title{
The construction mechanism of the Neoproterozoic S-type Sanfang-Yuanbaoshan granitic plutons in the Jiangnan Orogenic Belt, South China: Insights from geological observation, geochronology, AMS and Bouguer gravity modeling
}

Chaolei Yan, Liangshu Shu, Yan Chen, Michel Faure, Zuohai Feng, Mingguo Zhai

\section{- To cite this version:}

Chaolei Yan, Liangshu Shu, Yan Chen, Michel Faure, Zuohai Feng, et al.. The construction mechanism of the Neoproterozoic S-type Sanfang-Yuanbaoshan granitic plutons in the Jiangnan Orogenic Belt, South China: Insights from geological observation, geochronology, AMS and Bouguer gravity modeling. Precambrian Research, 2021, 354, pp.106054. 10.1016/j.precamres.2020.106054 . insu03085830

\author{
HAL Id: insu-03085830 \\ https://hal-insu.archives-ouvertes.fr/insu-03085830
}

Submitted on 23 Dec 2020

HAL is a multi-disciplinary open access archive for the deposit and dissemination of scientific research documents, whether they are published or not. The documents may come from teaching and research institutions in France or abroad, or from public or private research centers.
L'archive ouverte pluridisciplinaire HAL, est destinée au dépôt et à la diffusion de documents scientifiques de niveau recherche, publiés ou non, émanant des établissements d'enseignement et de recherche français ou étrangers, des laboratoires publics ou privés. 
1 The construction mechanism of the Neoproterozoic S-type Sanfang-Yuanbaoshan

2 granitic plutons in the Jiangnan Orogenic Belt, South China revealed by geological

3

4

5

6

\section{observation, geochronology, AMS and Bouguer gravity modeling}

$$
\begin{gathered}
\text { Chaolei Yan }{ }^{1,2,3} \text {, Liangshu Shu }{ }^{1, *} \text {, Yan Chen }{ }^{2}, \text { Michel Faure }^{2}, \text { Zuohai Feng }^{4} \text {, Mingguo } \\
\text { Zhai }
\end{gathered}
$$

${ }^{1}$ State Key Laboratory for Mineral Deposits Research, Nanjing University, 210023 Nanjing,

\section{China}

${ }^{2}$ Univ. Orléans, CNRS, BRGM, ISTO, UMR 7327, F-45071, Orléans, France

${ }^{3}$ Key Laboratory of Computational Geodynamics, University of Chinese Academy of Sciences, 100049 Beijing, China

${ }^{4}$ College of Earth Sciences and Guangxi Key Laboratory of Hidden Metallic Ore Deposits Exploration, Guilin University of Technology, Guilin, 541004 Guangxi, China

${ }^{5}$ Institute of Geology and Geophysics, Chinese Academy of Sciences, 100029 Beijing, China Corresponding author: Liangshu Shu (lsshu@nju.edu.cn)

\section{Abstract}

The Neoproterozoic S-type granitic plutons, distributed along the suture zone of the Yangtze and Cathaysia blocks, play an important role in the tectonic evolution of the Jiangnan Orogeny. However, few researchers had focused on the scientific issues on the physical construction process of these plutons. Therefore, we carried out multidisciplinary approaches on the Sanfang and Yuanbaoshan plutons in the western Jiangan Orogenic Belt to figure out the construction mechanism of these plutons. Zircon $\mathrm{Hf}$ and $\mathrm{U}-\mathrm{Pb}$ dating indicates that the magma, originated from the crustal partial melting, was crystallized at ca. 830 Ma. Field investigation shows that the plutons are dome shaped, and the bedding/foliation of the country rocks, the Sibao group, conform 
24 plutons boundaries and their inclinations gradually decrease away from the contact zone. A top-

25 to-the-E kinematic sense was observed in the eastern margin of Yuanbaoshan pluton. Both the

26 textural analysis and AMS measurement reveal primary magmatic and secondary general top-to-

27 the-W/NW post-solidus fabrics. The Bouguer gravity modeling reveals that the feeder zone

28 probably locates in the southern part of each pluton and these two plutons are connected at depth.

29 According to the primary magmatic fabric patterns, deep geometric shape as well as structural

30 features of the country rocks, we propose that crustal partial melting magma probably intruded

31 into the pre-existing mechanically weak (fold/fault) zone of the Sibao group, then lateral and

32 upward accreted to construct the dome-shape plutons. The timing and mechanism of the post-

33 solidus deformation are not well constrained, the interpretations are remain hypothetical.

34 Keywords: South China; Jiangnan Orogenic Belt; Neoproterozoic S-type granite; Anisotropy of 35 magnetic susceptibility; Bouguer gravity modeling

\section{$36 \quad 1$ Introduction}

Magmatic rocks are important constituents of the continental crust and good markers for the

38 crust evolution (Castro, 2014; de Saint-Blanquat et al., 2006; Paterson, 2009), and magmatic

39 activity plays a significant role in the crust-mantle interaction and recycling of crustal material

40 (Faure and Pons, 1991; Roman and Jaupart, 2016). Therefore, it is essential to study the

41 magmatism to have a better understanding of the magmatic process and the crustal evolution.

42 Several aspects, such as: i) magma generation, ii) differentiation, iii) transport and ascent, and iv)

43 emplacement, must be distinguished in the magmatic evolution (Glazner and Bartley, 2006). The

44 magma emplacement is an important stage of the process as it is the only one that can be directly

45 investigated through field and laboratory studies. During the emplacement, some features observed

46 both in the pluton and country rocks embody the interaction between the magma fluids and 
47 lithosphere as well as the mechanism of space accretion during the magma emplacement (Paterson 48 et al., 2008).

49 Previous studies showed that the magma intrusion are not only dominated by the physical 50 properties (i.e., magma composition, temperature, pressure and the rheology of the crust etc.), but 51 also controlled by syn-magmatic regional tectonic setting (Caricchi, et al., 2007; Castro, 1987;

52 Castro et al., 2014; de Saint-Blanquat et al., 2006; Hutton, 1988; Moyen et al., 2003; Pitcher, 1979;

53 Wei et al., 2016). Consequently, deciphering the process of magma emplacement, i.e., (1) the 3D 54 structure of the pluton (Cruden, 1988; Mathieu et al., 2008; O'Driscoll et al., 2006; Stevenson et 55 al., 2007); (2) granite internal fabrics (Liu et al., 2018; Tarling and Hrouda, 1993; Wei et al., 2014);

56 (3) the magma flow pattern (Clemens and Mawer, 1992; Ernst and Baragar, 1992; Moreira et al., 57 2015; Paterson, 2009); (4) the thermal conditions and deformation of the granite and country rocks 58 (Byerly et al., 2017; de Saint-Blanquat et al., 2001; Paterson et al., 1989; Žák et al., 2007), can 59 help to understand the evolutions of the granitic pluton and the continental crust.

60 S-type granite is considered as produced by partial melting and crystallization of Al-rich 61 rocks, such as orthogneiss and pelitic sedimentary rocks forming the lower to middle continental 62 crust. It is commonly accepted that peraluminous magma is a syn-to post-orogenic product formed 63 by the melting of the thickened orogenic root (Chappell and White, 2001). Moreover, S-type 64 granite may emplace in a post-orogeny setting (e.g., most of the post-orogenic plutons in the Early 65 Paleozoic orogen of SE China; Song et al., 2015; Wang et al., 2012b; Yan et al., 2017), and also 66 in an active continental margin (Cenozoic western Pacific; Collins and Richards, 2008).

67 In the Jiangnan Orogenic Belt (JOB), which marks the collision belt between the Yangtze and 68 Cathaysia blocks, the peraluminous granitic plutons sporadically crop out from east to west, such 69 as the Shexian, Xucun, Shiershan, Jiuling, Yuanbaoshan, Sanfang, Bendong and Fanjingshan 
70 plutons (Fig. 1). A large quantity of work on the geochronology and geochemistry suggest that

71 these plutons are post-orogenic ones (e.g., Shu, 2012; Shu et al., 2019; Wang et al., 2013, 2014b;

72 Yao et al., 2014a, Zhang and Wang, 2016; Zhang et al 2013).

73 So far, rare studies have focused on the physical construction process of the S-type granite in

74 the JOB, however it is essential for understanding the process of the Jiangnan Orogeny. The 75 geological observation, anisotropy of magnetic susceptibility (AMS) and gravity are efficient ways

76 to decipher the construction process and deep geometric shape of the plutons (Liu et al., 2018). In

77 order to obtain a better knowledge of the Neoproterozoic Jiangnan Orogeny, studies on the

78 emplacement of the Neoproterozoic S-type granitic plutons along the JOB as well as their detailed

79 consideration of the pluton construction, syn-magmatic and syn (post)-tectonic settings are

80 necessary. Consequently, we choose the Sanfang-Yuanbaoshan plutons as the study targets to

81 decipher the evolution of the Jiangnan Orogeny.

\section{$82 \quad 2$ Geological setting}

\subsection{The Jiangnan Orogenic Belt (JOB)}

The JOB is a key tectonic element of the South China Block, representing the Neoproterozoic

85 NE-SW to E-W trending belt developed as a consequence of the amalgamation between the

86 Yangtze and Cathaysia blocks. The oceanic subduction of the Paleo-South China Ocean beneath

87 the Yangtze Block since ca. $1000 \mathrm{Ma}$ (Shu et al., 2014, 2019; Wang et al., 2007; Yao et al., 2014b,

88 2019) was responsible for the formation of the Jiangnan magmatic arc, and followed by the

89 collision (or continental subduction) of the Cathaysia Block after its final closure (Shu, 2012;

90 Wang et al., 2012a). Groups of ultramafic, mafic magmatic, volcanic rocks, limestones, cherts and

91 turbidites are interpreted as ophiolites and dated from ca. $1000 \mathrm{Ma}$ to ca. $840 \mathrm{Ma}$, distributing 
92 along the suture zone (BGMRAH, 1982; BGMRJX, 1984; BGMRZJ, 1989; Shu et al., 2015, 2019;

93 Sun et al., 2017; Xia et al., 2018).

94 The Precambrian strata in the JOB are composed of the Sibao and Danzhou groups and their

95 equivalents. The Danzhou group unconformably covers the Sibao group. The unconformity

96 between these two groups indicates that an orogenic event took place before the sedimentation of

97 the Danzhou group and its equivalents. This collision resulted in essentially folding and weak

98 metamorphism (mainly under greenschist facies conditions) in the Sibao group and its equivalents

99 (BGMRGX, 1985; BGMRHN, 1988; Charvet, 2013; Shu, 2006, 2012). The tight NE-SW to N-S

100 striking folding and faulting are widely developed in the Sibao group and its equivalents in the

101 whole JOB resulted by the northwestward subduction of the Paleo-South China oceanic crust and

102 the subsequent collision of the Yangtze and Cathaysia blocks (Shu, 2012), whereas the structure

103 of the Danzhou group was characterised by broad and gentle folds with a weak metamorphism, or

104 even no metamorphism (BGMRGX, 1985; BGMRHN, 1988; Yao et al., 2014b).

105 In the JOB, the Sibao group was intruded by peraluminous granitic plutons dated at ca. 840-

106815 Ma with a peak of 830 Ma (e.g., Bendong, Fanjingshan, Sanfang, Shexian, Shiershan, Jiuling,

107 Xucun and Yuanbaoshan plutons; Fig. 1; Guo et al., 1989; Shu et al., 1991, 1994, 2019; Xin et al.,

108 2017; Yao et al., 2014b). After the formation of the original South China continent, the Nanhua

109 intracontinental rifting developed at ca. $810 \mathrm{Ma}-760 \mathrm{Ma}$ by probably upwelling mantle magma

110 just ending the Jiangnan Orogeny (Li et al., 2003). The NE-SW striking Nanhua rifting was coeval

111 with the generation of bimodal igneous rocks in the Jiangnan and Cathaysia regions, including the

112 western Yunnan, northern Guangxi, northern Hunan, northern Jiangxi, northern Zhejiang and

113 Northern Fujian basins (Li et al., 2008; Shu et al., 2006, 2011; Wang and Li, 2003). 


\subsection{Sanfang-Yuanbaoshan granitic plutons and country rocks}

115 The Sanfang and Yuanbaoshan granitic plutons are located in the western segment of the JOB

116 (Fig. 1), and show sub a N-S elongated elliptic shape with an area of ca. 1,000 km² and ca. 300

$117 \mathrm{~km}^{2}$, respectively, and an aspect ratio about 2:1 (Fig. 2).

118 These two granitic plutons both intruded into the Sibao group which is mainly composed of

119 bathyal to abyssal terrigenous arenaceous-argillaceous metasediments with bedded flysch, and 120 chaotic turbidity deposits with olistoliths (BGMRGX, 1985; Yao et al., 2014a). Previous studies

121 reveal that the crystallization age of these plutons ranged from $823 \pm 5$ Ma to $833 \pm 6$ Ma with

122 high Aluminium Saturation Index ranging in 1.15-1.40 (Yao et al., 2014b). Their geochemical

123 features indicate that the magma of Sanfang and Yuanbaoshan plutons were derived from

124 supracrustal source rocks (Wang et al., 2006). The widespread occurrence of tourmaline in these

125 plutons $(\mathrm{Li}, 1999)$ reveals that the granites are highly evolved and incorporated a significant 126 amount of fluids.

127 As for the deformation, $\mathrm{Li}$ (1999) proposed that all the granitic intrusions were deformed in 128 different degrees showing foliation with gneissic texture. Faults are developed in both plutons as 129 well as in their country rocks (Fig. 2), mainly striking in the NE-SW and N-S directions. Some 130 kilometer to meter- scale mafic and ultramafic blocks enclosed in the mudstone-sandstone of the 131 Sibao group crop out around the plutons. The well folded but low greenschist-facies 132 metamorphosed Sibao group is commonly recognized by the accretionary complex coeval with 133 the subduction of the Paleo-South China oceanic crust (Wang et al., 2014a; Zhou et al., 2009), and 134 recently work reveals that the upper Sibao group was deposited during the Yangtze-Cathaysia 135 continental collision (Yan et al., 2019). 
The Danzhou group unconformably covers the Sibao group, with distinct differences in the

137 deformation style. It mainly consists of sandstone and mudstone featured by gentle folds with a 138 low grade metamorphism, or even no metamorphism (BGMRGX, 1985).

\section{Field observation and microscopic investigation}

140 In the field, we made observations on these two plutons and their adjacent country rocks as 141 much as possible in order to obtain maximal information on macroscopic features of rocks with a 142 large surface covering, and figured out their geological nature.

\subsection{Granitic plutons}

144 The Sanfang and Yuanbaoshan plutons stand at a varying elevation ranging from ca. 200 to

145 ca. 2000 meters above sea level (a.s.1.). These two porphyritic monzogranitic plutons are mainly 146 made up of quartz, K-feldspar, plagioclase, muscovite and biotite. Tourmaline and plagioclase 147 nodules can be observed in some outcrops where the monzogranite shows fine or coarse grain 148 facies (Fig. 2).

149 It is worthy to note that these two plutons are generally undeformed in the relatively lower 150 part though some deformation can be occasionally observed in contact zone, whereas deformed in 151 the upper part (generally above 700 meters a.s.1.). In our visited localities, all the massive and 152 undeformed granites are at the relatively low elevation (e.g., A51: 566m, A55: 317m, B14: 234m, 153 B19: 329m). These undeformed granites display magmatic textures with euheral crystals of quartz, 154 feldspars and micas (Fig. 3A and 3B). The quartz grains show a slightly undulose extinction (Fig. $1554 \mathrm{~A}, 4 \mathrm{~B}$ and $4 \mathrm{C})$.

156 However, the most deformed granites crop out in the relatively higher part (e.g., A43: 993m, 157 A46: 983m, B08: 802m, B17: 837m).A consistent low angle ( 25 $\left.{ }^{\circ}\right)$ foliation is developed within 158 the deformed granites, dipping to the W and SW. Augen structure, gneissic structure and shear 
159 band are common in this deformed part. The mineral and stretching lineations are developed by

160 elongated quartz grains, biotite and muscovite aggregates, and pressure shadows around the K-

161 feldspar megacrysts trending in the E-W direction, with the top-to-the-W kinematics (Fig. 3C).

162 Moreover, in the highly deformed granites, the quartz and muscovite are totally recrystallized and

163 show a preferred orientation. Myrmekites develop within the K-feldspars (Fig. 4D), indicating that

164 the granites have experienced dynamic metamorphism as the myrmekite is an exolution of quartz 165 and plagioclase due to fluid circulation during deformation (Castle and Lindsley, 1993; Garcia et 166 al., 1996). And mica fishes from these two granitic plutons both show the top-to-the-W or -SW 167 kinematics (Fig. 4E and 4F).

$168 \quad 3.2$ Country rocks

169 The Sibao group is well exposed in the Sanfang-Yuanbaoshan area. Previous studies indicate 170 that the Sibao group was tightly folded with general N-S and NNE-SSW striking axes (BGMRGX, 171 1985). However, our investigation reveals that the structural occurrence of the Sibao group is also 172 accommodated to the shape of the pluton with generally outward dipping. The original 173 sedimentary bedding $\left(\mathrm{S}_{0}\right)$ and foliation $\left(\mathrm{S}_{1}\right)$ with moderate to steep angle mostly strike parallel 174 with the border of the Sanfang and Yuanbaoshan plutons (Fig. 2). Moreover, we can find that the 175 dip angle of the $\mathrm{S}_{0-1}$ gradually decreases as the distance away from the contact border (Fig. $3 \mathrm{E}$ and 176 3F). In our visited area, two hornfel outcrops with width of $20-30 \mathrm{~cm}$ are found in the western and 177 eastern contact borders between the Sanfang pluton and Sibao group (Fig. 3D). The top-to-the178 downward and -outward deformations are founded in the contact zones in the northern margin of 179 the Sanfang pluton and eastern margin of the Yuanbaoshan one (Fig. 3K). 
Previous studies also revealed a greenschist facies metamorphism for the Sibao group

181 (BGMRGX, 1985). Based on our macro-/microscopic observations, we found the degree of

182 deformation and metamorphism of the Sibao group varies greatly in different zones.

183 Similar to the phenomenon of elevation vs metamorphism and deformation within the granitic

184 plutons, in general, the degree of the metamorphism and deformation of the Sibao group seems

185 gradually increases from the lower part to the higher part, the field investigation revealed that: (i)

186 The Sibao group at the elevation below 200 meters mainly consists of sandstone and mudstone 187 and doesn't display metamorphism neither deformation (Fig. 3E and 3F); (ii) At the elevation of 188 ca. 200-700 meters, the degrees of the metamorphism and deformation are higher than those of 189 below the 200 meters. In this unit, the rocks mainly consist of slate and phyllite. The foliation $\left(\mathrm{S}_{1}\right)$ 190 transposed from the original sedimentary bedding $\left(\mathrm{S}_{0}\right)$ is rather scattily distributed, the lineations 191 are better developed with a sub E-W direction, meanwhile the textures reveal top-to-the-W 192 kinematics (Figs. 3G, 4G and 4H); (iii) For the Sibao group at the altitude higher than 700 meters, 193 the degrees of deformation and metamorphism are much more developed with respect to the former 194 lower parts. The original beddings $\left(\mathrm{S}_{0}\right)$ are well folded and even overturned as recumbent fold $\left(\mathrm{S}_{1}\right)$, 195 with the axis gently plunging to the north (Fig. $3 \mathrm{H})$. However, the later foliations $\mathrm{S}_{2}$ consistently 196 dip to the W with angles of $15-45^{\circ}$, with consistently oriented sub E-W lineations (Fig. 3I). 197 Moreover, mylonite and ultramylonite of the Sibao group were observed at the altitude of 10001981600 meters, with horizontal foliation and E-W directed lineation (Fig. 3J).

1994 Magma crystallization age and Hafnium isotopic analysis

200 The magma U-Pb crystallization age and geochemical features of the Sanfang and 201 Yuanbaoshan plutons have been investigated since the past twenty years (e.g., Li, 1999; Yao et 202 al., 2014b). With the recent development of analysis techniques, we have collected two dating 
samples, A37 (1403) and B13 (2024) (Figs. 2 and 7), to obtain constraints on the age of these

204 plutons.

\subsection{Zircon U-Pb age}

Heavy liquid and magnetic techniques are used for separating the zircon grains, which were

208 analyzed at the Testing Center of Shandong Bureau of China Metallurgical Geology Bureau

209 (TCSBCMGB), using a ThermoX2 ICP-MS connected to a GeoLas Pro $193 \mathrm{~nm}$ laser ablation

210 system. The detailed measurements and data calculation can be referred in Liu et al. (2010).

211 Cathodoluminescence (CL) images of zircons were acquired by using a JEOL JXA8230

212 electron probe microanalyzer at TCSBCMGB. Typical CL images of zircons are showed in Figure

$2135 \mathrm{~A}$ and 5B, revealing that the grains are characterized by oscillatory zoning. Moreover, the high

$214 \mathrm{Th} / \mathrm{U}$ values (0.35 in average) indicate the zircons are magmatic originated (Hoskin and

215 Schaltegger, 2003).

216 All of the U-Pb ages are listed in Table 1 and graphically displayed in Figure 5. Thirty seven 217 ages are obtained for each pluton (Sanfang and Yuanbaoshan), yielding the range of 814-1150 Ma 218 and 827-2720 Ma, respectively (Fig. 5D and 5G). However, most of the data provide ages between 219820 to $850 \mathrm{Ma}$ (Fig. $5 \mathrm{E}$ and $5 \mathrm{H}$ ), with weighted mean ${ }^{206} \mathrm{~Pb} /{ }^{238} \mathrm{U}$ ages of $830 \pm 2 \mathrm{Ma}$ and $830 \pm 5$

220 Ma, respectively (Fig. 5F and 5I). Some ages older than $2.0 \mathrm{Ga}$ may indicate the existence of 221 Paleoproterozoic rocks below the plutons. These grains may be xenocrystals involved in the 222 granitic magma.

\subsection{Zircon Hf isotopic analysis}

The zircon Hf isotopic model age tells a minimum age for the material from which the zircons

225 sourced. In order to have an idea about the evolution of the zircons, we carried out the analysis on 
226 the Zircon Hf isotopes by Neptune MC-ICP-MS at Nanjing University. For calculating the model

227 ages of the zircons, we used the standard zircon 91500 as external sample with a ${ }^{176} \mathrm{Hf} /{ }^{177} \mathrm{Hf}$ value

228 of $0.282300 \pm 8(2 \sigma)$. During analysis, the ${ }^{176} \mathrm{Lu} /{ }^{177} \mathrm{Hf}$ of average crust is 0.015 . Lu decay constant

229 of $1.865 \times 10^{-11}$ was applied for the calculation of the initial ${ }^{176} \mathrm{Hf} /{ }^{177} \mathrm{Hf}$ values (Scherer et al., 2001).

230 The isotopic ratios of the ${ }^{176} \mathrm{Hf} /{ }^{177} \mathrm{Hf}$ and ${ }^{176} \mathrm{Lu} /{ }^{177} \mathrm{Hf}$ for the chondrite and depleted mantle are

2310.282772 and $0.0332,0.28325$ and 0.0384, respectively (Blichert-Toft and Albarede, 1997).

232 About half of the $\mathrm{U}-\mathrm{Pb}$ dated zircons from the Sanfang granite were selected for in-situ $\mathrm{Hf}$

233 isotopic analysis that performed where used for $\mathrm{U}-\mathrm{Pb}$ dating. All of the $\mathrm{Hf}$ isotopic analytical

234 results and $\varepsilon \mathrm{Hf}(\mathrm{t})$ versus $\mathrm{U}-\mathrm{Pb}$ age diagram are presented in Table 2 and Figure 5C, respectively.

235 The sample of A37 (1403) shows negative $\varepsilon \mathrm{Hf}(\mathrm{t})$ values, ranging from -1.89 to -11.15 , with an

236 average of -4.63 . Correspondingly, the two-stage model ages chiefly plot on 1828-2143 Ma, while

237 separately project at $2418 \mathrm{Ma}$ (Fig. 5C). The results suggest that such granite sample was derived

238 from some Paleoproterozoic basement rocks. Moreover, all the $\varepsilon \mathrm{Hf}(\mathrm{t})$ values are under the

239 Chondritic uniform reservoir (CHUR) line, which indicates that little or no mantle component has

240 been involved into the source rock during the partial melting and magma ascent.

\section{Rock magnetic investigation and results}

\section{$242 \quad 5.1$ Field sampling}

243 A total of 352 cores from 55 sites were sampled for the AMS study, 35 and 20 for the Sanfang

244 and Yuanbaoshan plutons, respectively, along all possible roads with an interval of $\sim 2 \mathrm{~km}$ (Fig.

245 7). Each site of fresh outcrop covers several tens of square meters and at least six cores are drilled 246 with an interval of 3 to 4 meters between each other from each site. 
248 In order to define the magnetic susceptibility carriers in our samples, we have carried out 249 following methods: (1) magnetic hysteresis loop characterization by using a vibrating 250 magnetometer in the Laboratoire de Paleomagnétisme of the Institue de Physique du Globe de 251 Paris (IPGP); (2) isothermal remanence magnetization characterization with an IM30 pulsed 252 magnetizer and a JR5 spinner magnetometer at the Insititut des Sciences de la Terre d'Orléans 253 (ISTO); (3) thermomagnetic characterization using a KLY5 kappabridge coupled with a CS3 254 furnace at ISTO; and (4) scanning electron microscope (SEM) with the ZEISS MERLIN Compact 255 for the minerals at ISTO.

256 A total of nine samples were chosen for magnetic mineralogical analysis, and the 257 representative results are presented in Figure 6. The hysteresis curves (Fig. 6A) present similar S258 shaped hysteresis loops with significant difference between the corrected and uncorrected curves, 259 suggesting that the main magnetic susceptibility carriers could be both ferromagnetic and 260 paramagnetic minerals. Rapid saturation of isothermal magnetic remanence at about $200 \mathrm{mT}$ is 261 featured by Sample A46 (Fig. 6B), indicating the existence of ferromagnetic minerals with low 262 magnetic coercivity. However, for Sample A48, the gradual saturation until to 1.0 Tesla (Fig. 6B) 263 highlights that the existence of ferromagnetic minerals with high magnetic coercivity. The rates of 264 saturation of Samples A65 and A67 are in-between A46 and A48 (Fig. 6B), revealing both the 265 weak and high coercive ferromagnetic minerals in the granites. The thermomagnetic 266 measurements on Samples A10 and A23 yield a quick decrease of the magnetic susceptibility at 267 about $580^{\circ} \mathrm{C}$ (A10 in Fig. 6C) and continuous drop until to $680^{\circ} \mathrm{C}$ (A23 in Fig. 6C), which suggest 268 the existence of (titano) magnetite and hematite. Moreover, these two samples show a continuous 269 rise of magnetic susceptibility in the cooling stage (owing to oxidation reactions) revealing that a 
270 significant mineral transformation occurred during the heating, e.g. iron sulfide to iron oxide (Fig.

271 6C). The SEM investigation reveals that the existence of titanomagnetite with the mass fraction of

272 the $\mathrm{TiO}_{2}$ ranged from $45.51 \%$ to $50.65 \%$, and they are commonly intergrown or partly enclosed

273 along the cleavage and boundary of biotite (Fig. 6D). The Day-plot of hysteresis parameters is

274 presented in Figure 6E, showing that (titano) magnetite of the measured samples drop in the

275 multidomain zone (e.g., Dunlop, 2002). It indicates that the major (elongated) axis of the magnetic

276 susceptibility ellipsoid can be correlated to the major morphological axis of minerals (e.g.,

277 Borradaile and Henry, 1997).

278 Consequently, the carriers of magnetic susceptibility are composed by ferromagnetic 279 minerals, for instance, multidomain (titano) magnetite and hematite, and of paramagnetic minerals, 280 such as biotite, muscovite and feldspar. According to Rochette et al. (1992), the magnetic fabrics 281 of these minerals are comparable to the petrographic ones. Therefore, the AMS measurements will 282 be an effective way to obtain the information on the petrofabrics of granite, so that to decipher the 283 granitic magma emplacement (Martín-Hernández et al., 2004).

$284 \quad 5.3$ AMS parameters

285 The measurements of AMS were performed with a KLY5 Kapprabridge at ISTO. A total of 286352 (228 and 124 from the Sanfang and Yuanbaoshan, respectively) specimens with $2.5 \mathrm{~cm}$ in 287 diameter and $2.2 \mathrm{~cm}$ in length from 55 sites were prepared. Detailed information can be found in 288 Table 3. The mean bulk magnetic susceptibility (Km) of each sampling site from the Sanfang and 289 Yuanbaoshan plutons varies from 27.5 to $133.0 \times 10^{-6}$ SI and 32.7 to $197.0 \times 10^{-6}$ SI, respectively 290 (Fig. 8A, 8B and 8D). The site-mean value of the anisotropy degree of the magnetic susceptibility 291 ( $\left.\mathrm{P}_{\mathrm{J}}\right)$ ranges in $[1.017,1.156]$ and $[1.009,1.172]$ for the Sanfang and Yuanbaoshan plutons, 292 respectively (Fig. 8B, 8C and 8E). The site-mean of shape parameter (T) ranges in [-0.384, 0.912] 
293 and [-0.384, 0.817] for the Sanfang and Yuanbaoshan, respectively (Fig. 8C and 8F). No obvious

294 correlation of $\mathrm{P}_{\mathrm{J}}$ can be observed with Km (Fig. 8B) and elevation (Fig. 8C), however, the $\mathrm{P}_{\mathrm{J}}$ and

$295 \mathrm{~T}$ are positively related (Fig. 8F). Moreover, $\mathrm{P}_{\mathrm{J}}$ and $\mathrm{T}$ values both increase with the rising of

296 elevation (Fig. 8D and 8E), which is illustrated in the cross section of Figure 8H.

\subsection{AMS results} significant between the undeformed and deformed granites according to the features of their magnetic foliation and lineation, degree of anisotropy and shape parameter (Figs. 7 and 8). In our

301 visiting area, the undeformed granites with magmatic fabrics can be roughly partitioned as NW 302 and SW borders, S part, and SE border of the Sanfang pluton, and SE part and NE border of the 303 Yuanbaoshan pluton, meanwhile in order to read easily, these zones are also shown by Arabic 304 numbers 1, 2, 4 and 6, respectively in Figure 8. In the NW and SW borders of the Sanfang pluton 305 (Zone 1), the magnetic foliations consistently dip to the $\mathrm{E}$ with the inclination ranged from $33^{\circ}$ to $30679^{\circ}$, but the magnetic lineations span from $\mathrm{N}$ to $\mathrm{S}$ with a relative concentration on the SE dipping. 307 Almost all the specimens show $\mathrm{P}_{\mathrm{J}}$ value lower than 1.1 and magmatic fabrics with even shape 308 parameters between oblate $(T>0)$ and prolate $(T<0)$. In the $S$ part of the Sanfang pluton (Zone 2), 309 the magnetic foliations mainly dip to the $\mathrm{W}$ with inclinations varying from $31^{\circ}$ to $63^{\circ}$, and 310 magnetic lineations span from $\sim 230^{\circ}$ to $330^{\circ}$, with a relative concentration in nearly E-W directed.

$31194 \%$ of the specimens have PJ values lower than 1.1 and the ratio between the oblate and prolate 312 shapes is about 2:1. The SE border of the Sanfang pluton (Zone 4) displays the gentle magnetic 313 foliations with dispersed magnetic lineations. All the $\mathrm{P}_{\mathrm{J}}$ values are lower than 1.1 and the ratio of 314 shape parameter between the oblate and prolate is about 2:1. Moreover, in the SE part and NE 315 border of the Yuanbaoshan pluton (Zone 6), the strikes of the magnetic foliations mainly dip SW 
316 with relative steep inclinations from $35^{\circ}$ to $76^{\circ}$, and the magnetic lineations are essentially SSE.

317 Most of the $\mathrm{P}_{\mathrm{J}}$ values are lower than 1.1, and the ratio between the oblate and prolate shapes is 318 about 1:1.

319 However, the deformed granites are recognized in the Central to NE Sanfang pluton and in 320 the Central to NW Yuanbaoshan pluton (Zones 3 and 5, respectively; Fig. 8). In the Central to NE 321 part of the Sanfang pluton (Zone 3), the $\mathrm{P}_{\mathrm{J}}$ values, with the range from 1.041 to 1.187, are higher 322 than other zones in the Sanfang pluton. $37 \%$ of the specimens with the $P_{J}$ value higher than 1.1, 323 suggesting that the magnetic fabric could have been modified in the post-solidus state (Tarling and 324 Hrouda, 1993). The magnetic foliations gently dip to the SW, with coherent NEE-SWW directed 325 magnetic lineations. More than $95 \%$ of the shape parameters of specimens are greater than zero, 326 i.e., oblate shape. Similarly, the Central to NW part of the Yuanbaoshan pluton (Zone 5) highlights 327 PJ values ranging from 1.017 to $1.183 .57 \%$ of sites in this zone provide $P_{J}$ values higher than 1.1, 328 and almost all of these sites present positive values for shape parameter, i.e., oblate shape. They 329 show moderate magnetic foliations dipping ranging from $4^{\circ}$ to $27^{\circ}$, with consistent NW-SE 330 directed magnetic lineations.

331 Consequently, the AMS results of these two plutons can be divided into two aspects, namely, 332 the magmatic fabric and tectonic one, corresponding to the undeformed and deformed granites, 333 respectively (Figs. 7 and 8). These two parts seem to be qualitatively distinguished at the 334 approximate altitude of $600-800 \mathrm{~m}$. To simplify the description, we utilize the average altitude line 335 of $700 \mathrm{~m}$ as the separatrix between the undeformed and deformed granites.

336 Moreover, it is worth noting that a few samples (about less than 5 per cents) show the 337 incoherent results with respect to above description. The samples B01, B03 and B04 are in the 338 relative low elevation $(\sim 500 \mathrm{~m})$, but their petro/magnetic fabrics seem like a tectonic origin, with 
obvious sigmoid feldspar and high $\mathrm{P}_{\mathrm{J}}$ values ranges in [1.064, 1.079] (Fig. 7), therefore, these

340 localities have been classified to Zone 5. Meanwhile, the samples A48, A60 and A61 are in the

341 relative higher part, but displaying massive granite and lower $\mathrm{P}_{\mathrm{J}}$ values ranges in $[1.026,1.042]$

342 compared to the ductilely deformed granites (Figs. 7 and 8G), hence, these localities are

343 categorized in Zone 1. Furthermore, the two massive granite samples A33 and B11 display

344 different magnetic features with respect to the adjacent ones, showing vertical magnetic foliations

345 and gentle lineations which are all parallel to the boundary between the granitic plutons and 346 country rocks (Fig. 9).

347 In order to have an integrated view of features of the magnetic foliations and lineations, a 348 synthetic distribution map of magnetic foliations and lineations are presented in Figure 9.

349 Generally, the magnetic foliations and lineations can be separated into two parts as previously

350 documented, respectively. For the magmatic fabrics, the predominant strike of the foliation of the

351 Sanfang and Yuanbaoshan plutons is sub N-S directed, and the secondary group is sub E-W 352 directed. Two major groups of lineations are identified in the Sanfang pluton, namely the NEE353 SWW and NNW-SSE directed ones. And the distinct magmatic lineations are sub NNW-SSE 354 directed in the Yuanbaoshan pluton. However, for the tectonic fabrics, a set of consistent gentle 355 SW dipping magnetic foliation and gently SWW directed magnetic lineation is recognized in the 356 Sanfang pluton. Whereas dispersed magnetic foliations with gentle inclination are identified in the 357 deformed granite in the Yuanbaoshan within a group of gently NW directed magnetic lineations 358 (Fig. 9).

\section{Gravity modeling}

360 The regional gravity anomaly embodies the density heterogeneity of the underground, hence, 361 the proper decipherment of the gravity anomaly data would help us to know the construction of 
362 the geological bodies in the deep (Martelet et al., 2013), especially, the intrusive geological bodies

363 usually present obvious density contrast with the wall rocks. Consequently, the gravity modeling

364 method has been applied to deduce the Sanfang and Yuanbaoshan pluton shapes within the Sibao

365 strata. The Bouguer gravity anomaly map for the Sanfang-Yuanbaoshan area is acquired at the

366 China Geological Survey. The Digital Elevation Model (DEM) for the Sanfang-Yuanbaoshan area

367 is obtained from the CGIAR-CSI database.

368 We collected both the granites and country rocks for the density measurements, which have

369 been carried out at the University of Nanjing by using the Matsuhaku Electronic Densimeter GH-

370300 . For each sample, we measured twice and took the average value at a precision of $0.001 \mathrm{~g} / \mathrm{cm}^{3}$.

371 Detailed density data for the samples from the granites, Sibao group, Danzhou group and Sinian

372 strata can be referred in Table 4. As the post Sinian strata is poorly exposed, we take it as same as

373 the density of the Sinian strata. Besides, the density of the mafic-ultramafic block is referred to the

374 geological survey of the Guangxi province (BGMRGX, 1985). The density value of $2.670 \mathrm{~g} / \mathrm{cm}^{3}$

375 for the background in the study area is referred in CRUST 1.0.

376 In the Bouguer gravity anomaly data, both the short and long wavelength signals are involved,

377 which reflect the surface and deep signatures, respectively. Thus the long wavelength signals

378 should be removed for the purpose of getting appropriate gravity anomaly information just induced

379 by the sub-surface geological units. The Butterworth Low-Pass Filter is applied for removing the

380 long wavelength signals with cut-off wavelengths of $10,20,30 \ldots$ to 130,140 and 150 kilometers.

381 Through the comparison of the residual gravity anomaly and geological maps, we found that the

382 residual gravity anomaly with the cut-off wavelength of $130 \mathrm{~km}$ is the most suitable one, which

383 matches best with ground surface features (Fig. 10). 
The selected residual Bouguer gravity anomaly map shows two obvious negative anomaly

385 centers in the central and southern parts of the Sanfang and Yuanbaoshan plutons, respectively

386 (Fig. 10). The negative anomaly regions for these two plutons are both N-S directed, which concur

387 the geometry of these two plutons. According to the residual Bouguer gravity anomaly data and

388 regional tectonic features, five profiles are chosen for gravity modeling, two of them (WE1 and

389 WE2) are perpendicular to the regional tectonic lines, and three (NS1, NS2 and NS3) are parallel

390 with the regional structures.

$391 \quad$ Five interpreted profiles are presented in Figure 10. Their deep structures are modelled with 392 the residual Bouguer gravity anomaly data, however, the surface contact relationship between each 393 unit is depicted according to the field observations and geological maps (BGMRGX, 1985). 394 According to the Bouguer gravity modeling along these profiles, we can characterize these two 395 plutons as following: (1) Negative gravity anomalies are N-S long axis orientated within the Sibao 396 group; (2) The roots of the granitic plutons are presented in a N-S orientated dyke shape; (3) In the 397 E-W direction, two plutons are in a tongue shape; (4) For the Sanfang pluton, the deepest root is 398 located in its southern part, and the depth is progressively decreased northwards with the 399 shallowest depth of ca. 0.5-1 km in its northern part; (5) For the Yuanbaoshan one, the thickest 400 part is situated in the central pluton; (6) The Sanfang and Yuanbaoshan plutons seem to be 401 connected in the deep.

\section{Discussion}

$403 \quad$ 7.1 Origin of the magma and its crystallization age

404 Numerous researches have studied the petrogeneses and tectonic settings of the 405 Neoproterozoic granites in the JOB, the Neoproterozoic S-type granitic plutons in the JOB have 406 been dated with U-Pb crystallization ages ranged from 840 to $815 \mathrm{Ma}$, peaking at ca. $830 \mathrm{Ma}$ (e.g., 
407 Wang et al., 2006; Wu et al., 2006; Xue et al., 2010; Zhong et al., 2005). Besides, these plutons

408 are characterised by the high Aluminium Saturation Index ranging from 1.15 to 1.40 (Yao et al.,

$4092014 \mathrm{~b}$ and references therein) and low initial $\varepsilon \mathrm{Nd}$ values from -4.8 to -7.6 with high enrichment in

$410 \mathrm{Rb}, \mathrm{K}$ and Th elements ( $\mathrm{Li}, 1999)$. Thus the geochemical features indicate that the granites were

411 sourced from supracrustal rocks (Wang et al., 2006).

412 In this study, several methods are carried out for deciphering the origin of the magma.

413 Petrologically, the granite samples are K-feldspar megacryst rich (Fig. 3C). Structurally, the

414 cathodoluminescence (CL) images (Fig. 5A and 5B) show zircons with clear oscillatory zoning,

415 revealing the typical feature of zircons from acidic magma. Isotopically, moreover, all of the $\varepsilon \mathrm{Hf}(\mathrm{t})$

416 values are under the CHUR line (Fig. 5C), suggesting the melting of magma with little or even no

417 mantle components. Consequently, we suggest the granites of the Sanfang and Yuanbaoshan

418 plutons were generated by the partial melting of crustal materials, furthermore, the relatively

419 homogeneous lithological features of these granitic plutons may suggest that the magma was

420 derived from single component within the chamber.

421 Moreover, the new zircon results from the Sanfang and Yuanbaoshan granites provide the

422 mean ages of these two plutons at $830 \pm 2 \mathrm{Ma}$ and $830 \pm 5 \mathrm{Ma}$, respectively (Fig. 5F and 5I), which

423 further indicates the magma crystallized at ca. 830 Ma. Few zircon grains give ages older than 2.0

424 Ga (Fig. 5G), indicating that a Paleoproterozoic basement probably exists below the upper crust

425 in this area, and these old zircons were captured during the magma ascent. Furthermore, the Hf 426 isotopic analyses show a group of two-stage model ages at ca. 1800-2400 Ma, which suggest the 427 possible existence of Paleoproterozoic rocks beneath the JOB. 


\subsection{Acquisition of magnetic fabrics}

429

430

431

432

433

434

435

436

437 Sanfang pluton. The microscopic investigations show that quartz grains are euhedral with slightly

438 undulose extinction (Fig. 4A and 4B), however, the biotite grains in the granite do not show any

439 post-solidus deformation (Fig. 4B). These evidence suggest the granites have not suffered

440 significant post-solidus deformation. Furthermore, $96 \%$ of the $\mathrm{P}_{\mathrm{J}}$ values in this domain lower than

441 1.1, which indicates that the magnetic fabrics were probably acquired during the magma

442 crystalization (Borradaile and Henry, 1997). Therefore, we propose that the magnetic fabrics in

443 this domain are primary ones, i.e. without post-solidus overprint due to post-emplacement

444 geological events. The shape parameters indicate both oblate and prolate shapes with equivalent

445 proportion, which indicates that the magnetic foliation and lineation were almost equally

446 developed, thus we may propose that the original magma probably flowed without significant

447 influence of a regional tectonics (Tarling and Hrouda, 1993).

448 On the contrary, in the post-solidus domain (Zones 3 and 5 in Fig. 8G) at altitudes above

$449 \sim 700 \mathrm{~m}$ a.s.1., the granites are foliated with augen gneissic structures and shear bands. Microscopic

450 studies reveal that the quartz grains are mostly recrystallized as neograins with serrated boundaries, 
451 showing the evidence of high temperature and high strain deformation. A top-to-the-W kinematics

452 is macroscopically documented by the sigmoidal augen structure and shear bands, and 453 microscopically by mica fish and pressure shadows. In addition, the $\mathrm{P}_{\mathrm{J}}$ values of this zone are 454 generally higher than 1.1, i.e., higher than those in the magmatic domain, suggesting that the 455 magnetic fabrics were acquired after the magma cristalization. Moreover, it is worthy to note that 456 almost all the shape parameters for the specimens in this domain are greater than zero (Fig. 8G), 457 indicating the planar magnetic fabric is more developed than the linear magnetic one probably due 458 to the deformation posterior to the crystallisation. Thus, the evidence above reveals that the 459 magnetic fabrics of this domain are secondary, i.e., the synmagmatic ones are overprinted. 460 However, the formation time of these post-solidus fabrics is not yet constrained, they might have 461 been developed during the later stage of the magma emplacement or recrystallized during regional 462 tectonic events that post-dated the plutons emplacement (Tarling and Hrouda, 1993). As this is out 463 of the scope of this study, the possible hypotheses for this ductile deformation will not be discussed 464 in detail in this text.

\subsection{Mechanism of the magma emplacement and space creation}

In this section, we concentrated on the lower part (primary magmatic fabrics) of the plutons

467 and their wall rocks to decipher the magma emplacement process of the Sanfang and Yunabaoshan 468 plutons, using our macro/micro observations, geochronological results, fabric measurements, 469 gravity modelling as well as the previous data.

\subsubsection{Sanfang pluton}

The Sanfang pluton is elliptic shaped in the N-S long axis. Previous geological survey reveals 472 that both of the granitic plutons and their country rocks are cut by the sub N-S directed faults, 
473 which were probably generated in the Neoproterozoic period and reactivated in the Paleozoic or 474 in the Mesozoic (Fig. 2).

475 Our field investigation indicates that the bedding of the Sibao group close to the Sanfang 476 pluton conform the geometry of the pluton, the original sedimentary bedding $\left(\mathrm{S}_{0}\right)$ and foliation $\left(\mathrm{S}_{1}\right)$ 477 are nearly parallel with the border of the granite, suggesting a dome shaped pluton (Fig. 2). 478 Moreover, the dip angle of the $\mathrm{S}_{0-1}$ gradually decreases as the strata away from the contact border 479 (Fig. 3E and 3F). At the exposure level, the Sanfang pluton seems having rarely heated the country 480 rocks with no evidence for obvious thermal aureole, and hornfels have been only observed in two 481 localities in the contact boundary (Fig. 3D), with length $3 \sim 5 \mathrm{~m}$ by width $20 \sim 30 \mathrm{~cm}$. This means that 482 the amount of heat was not so large and thus we can infer that the first magma injection was 483 probably in a small volume. It probably reveals that the magma injections took place though multi 484 episodic injections but with a small magma volume at each injection, which could be referred to 485 magma pulse amalgamation (Fig. 11; de Saint-Blanquat et al., 2006; Horsman et al., 2005).

486 In the NW and SW borders of the Sanfang pluton (Zone 1), the magnetic foliations dip E487 wards with moderate dipping angles $\left(31-60^{\circ}\right)$, whereas the magnetic lineations in this zone show 488 two direction groups, i.e., sub E-W plunging with steep angles $\left(61-90^{\circ}\right)$ in the southern part, and 489 N-S plunging with gentle angles $\left(0-30^{\circ}\right)$ in the northern part (Fig. 9). Moreover, in the southern 490 part of the Sanfang pluton (Zone 2), the foliations dipping W-wards with steep angles and mainly 491 W-dipping lineations may imply that the magma dominantly flowed quasi vertically and accreted 492 in the E-W direction. Furthermore, the magnetic foliations dip SE/SW-wards with moderate angles, 493 and the magnetic lineations generally show a sub E-W preferred orientation in the SE border of 494 the Sanfang pluton (Zone 4, Figs. 8 and 9). 
From the integrated results, it is obvious that the magmatic foliations of the Sanfang pluton

496 can be roughly distinguished as two sets, namely, the sub N-S striking (major) and sub E-W 497 striking (minor). Meanwhile, the orientations of the magmatic lineations seem more scattered (Fig. 498 9).

499 The residual Bouguer gravity anomaly data show that the Sanfang pluton is also N-S 500 elongated at depth, and reveal that the root of the Sanfang pluton is located in its southern part. 501 And the interpreted profile NS1 suggests that the thickness of the Sanfang pluton decreases 502 northwards (Fig. 10). From the unravelled profiles WE1 and WE2, moreover, the dyke shaped 503 channels seem to be characterized in the pluton.

\subsubsection{Yuanbaoshan pluton}

The geometry of the Yuanbaoshan pluton is N-S elongated with an aspect ratio of 2:1. The field observation shows that the pluton geometric shape also well affects the occurrence of the 507 country rocks of the Sibao group, i.e., the bedding of the sedimentary rocks follows the shapes of 508 the pluton (Fig. 2). This appearance seems becoming weaker leaving away the pluton. The sigmoid 509 quartz vein within the Sibao group locates to the east of the Yuanbaoshan pluton might be 510 interrelated with the ductile shearing during the magma emplacement since such top-to-the-E 511 kinematic is rarely developed in the study area except in the contact area between the eastern 512 Yuanbaoshan pluton and its country rock (Fig. 3K). In the SE part and NE borders (Zone 6) of this

513 pluton, the strikes of the magmatic foliations are principally NNW-SSE directed with steep and 514 even vertical inclinations. And the magmatic lineations are mostly sub N-S directed and few NW515 SE directed with gentle dipping angles (Fig. 9), suggesting that the magma might vertically ascend 516 and mainly horizontally flow in the sub N-S direction in these parts. Moreover, two samples of 517 B02 and B11, close to the boundary between the Yuanbaoshan pluton and Sibao strata, display 
518 foliation with moderate to vertical inclination, and gentle lineations which parallel to the boundary

519 of country rocks. It may suggest that the magma probably flowed along the boundary of the country 520 rocks (Fig. 11).

521 Moreover, the residual Bouguer gravity anomaly yield that the root of the pluton is located in 522 the central to southern part (Fig. 10). Similar to the case of Sanfang pluton, the inferred profiles

523 NS2 and NS3 suggest that the thickness of pluton is slightly decreasing from south to north, and 524 the profiles WE1 and WE2 suggest that the dyke shaped channels seem alike also within the 525 Yuanbaoshan pluton.

\subsubsection{Construction processes of the two plutons}

527 Following observations and results may help to understand the pluton construction process:

528 1. the strata surrounding the pluton strike parallel to its border with progressive decrease of the 529 bedding inclination; 2 . magnetic fabric patterns are characterised by principal sub N-S striking 530 foliation and partial sub E-W ones with relatively dispersed lineations for the Sanfang pluton and 531 sub N-S directed ones for the Yuanbaoshan pluton; 3. gravity modelling reveals a thick 'root' 532 located in the central to south part of the plutons with possible N-S directed dyke-shaped channels. 533 By integrating the above phenomena, we propose that the magma probably made its 534 upwelling into the Sibao group in the central to southern part of the plutons through dyke-shaped 535 channels, probably resulted by the pre-existing abundant and large-scale folds/faults within the 536 Sibao group, and laterally pushed the country rocks outwards. Due to probably the shape of pre537 existing structures, i.e. N-S oriented folds/faults, the magma dominantly flowed north-southwards 538 to construct the tongue- and/or sill-shaped plutons. Meanwhile, the granitic bodies were 539 progressively accreted in sub E-W direction to form the principal sub N-S oriented foliation. 540 Therefore, the N-S flow of magma and E-W accretion of pluton seem likely forming two dome 
541 shaped plutons (Fig. 11). Nevertheless, the depth of emplacement is unclear and worthy for future

542 investigation.

$543 \quad 7.4$ Tectonic implications and perspectives

544 S-type granitic plutons are interesting geological markers to understand the tectonic process,

545 numerous such plutons are distributed along the JOB. However, their tectonic setting is still hotly

546 debated in the past decade. Some scholars suggested that the peraluminous plutons were generated

547 and made their intrusion during the amalgamation of the Yangtze and Cathaysia blocks, i.e., the

548 syn-orogenic stage, while considering the coeval mafic rocks dated at ca. 850-830 Ma (Ding et al.,

549 2008; Zhou et al., 2004). Nevertheless, some others hold the view that the granitic plutons were

550 formed at the post-orogenic stage (Wang et al., 2013; 2014b; Yan et al., 2019; Zhang et al., 2013,

551 2016). These suggestions are, however, proposed only on the basis of the geochronological logic,

552 without direct geological and physical evidence.

553 In this study, the field observations show some pluton emplacement related deformation in

554 the country rocks, but no any evidence for a syn-magmatism regional scaled tectonic deformation.

555 The primary magmatic fabrics in both plutons seem having been acquired in a regional tectonic

556 free environment. Thus we propose that the crustal partial melting magma in the western Jiangnan

557 area might be produced by the thickened crust and emplace into the Sibao group during a period

558 of tectonic quiescence, in other words, the S-type granitic magma emplacement probably signifies

559 the ending stage of the Jiangnan Orogeny.

560 However, the timing and mechanism of the top-to-the-W post-solidus deformation

561 distinguished by the macro-/micro observations, and AMS study is still poorly studied. Two

562 possible hypotheses are supposed, one is that the deformation occurred during the magma intrusion

563 at ca. $830 \mathrm{Ma}$, whereas the other one is that it maybe caused by the Paleozoic or Mesozoic tectonic 
564 events. However, the latter one is puzzled because of the regional deformation/metamorphism is

565 not yet recognized in the Jiangnan region (Shu, 2012 and references therein). In order to solve

566 these scientific issues, detailed field work on the regional deformation as well as the

567 geochronology study, e.g., Ar-Ar dating, should be carried out in the further research.

\section{$568 \quad 8$ Conclusions}

569 Through this multidisciplinary study, the emplacement process and tectonic setting of the

570 Neoproterozoic S-type Sanfang-Yuanbaoshan granitic plutons in the JOB can be concluded as

571 following:

572 (1) The magma of the plutons sourced from the partial melting of crustal material, and 573 crystallized at ca. $830 \mathrm{Ma}$;

574 (2) Magnetic/petrographic fabrics can be divided into two groups, namely, a primary sub575 solidus, or magmatic, fabric developed during the pluton emplacement; and a secondary post576 solidus, or solid-state, one related to a still uncertain tectonic process;

577 (3) The crustal partial melting magma probably intruded into the pre-existing mechanically 578 weak (fold/fault) system in the Sibao group through dyke-shape channels, and afterwards 579 dominantly flowed north-southwards to construct the tongue- and/or sill-shaped plutons, 580 meanwhile, the granitic bodies were progressively accreted in sub E-W direction to form two dome 581 shaped plutons;

582 (4) The intrusion of the S-type granitic magma probably occurred in a regional tectonic free 583 environment, the emplacement probably marked the latest stage of the Jiangnan Orogeny.

\section{Acknowledgments}

585 We wish to express our thanks to Drs. Liu Hongsheng and Wei Wei for their help on the 586 analyses of AMS and Bouguer gravity modeling. This study is supported by the National Key R 
\& D Program of China [No. 2016YFC0600202], National Natural Science Foundation of China

588 [Nos. 41772204], Major Program of National Natural Science Foundation of China [Grant 589 Nos. 41890834] and Natural Science Foundation of Guangxi [Grant Nos. 2019GXNSFDA245009].

590 We also gratefully acknowledge financial support by China Scholarship Council. Datasets related 591 to this article can be found at https://doi.org/10.6084/m9.figshare.11858388.

\section{References}

593 BGMRAH (Bureau of Geology and Mineral Resources of Anhui Province)., 1982. Regional 594 Geology of Anhui Province [in Chinese with English Abstract]. Geological Publishing $595 \quad$ House, Beijing, pp. 1-715.

596 BGMRGX (Bureau of Geology and Mineral Resources of Guangxi Province)., 1985. Regional 597 Geology of Guangxi Autonomous Region [in Chinese with English Abstract]. Geological $598 \quad$ Publishing House, Beijing, pp. 1-853.

599 BGMRHN (Bureau of Geology and Mineral Resources of Hunan Province)., 1988. Regional 600 Geology of Hunan Province [in Chinese with English Abstract]. Geological Publishing $601 \quad$ House, Beijing, pp. 6-664.

602 BGMRJX (Bureau of Geology and Mineral Resources Jiangxi Province)., 1984. Regional Geology 603 of Jiangxi Province [in Chinese with English Abstract]. Geology Publishing House, Beijing, $604 \quad$ pp. $2-725$.

605 BGMRZJ (Bureau of Geology and Mineral Resources Jiangxi Province)., 1989. Regional Geology 606 of Jiangxi Province [in Chinese with English Abstract]. Geology Publishing House, Beijing, 607 pp. 5-575. 
608

609

610

611

612

613

614

615

616

617

618

619

620

621

622

623

624

625

626

627

628

629

Blichert-Toft, J., Albarede, F., 1997. The Lu-Hf isotope geochemistry of chondritesand the evolution of the mantle-crust system. Earth Planet. Sci. Lett. 148, 243-258. https://doi.org/10.1016/s0012-821x(97)00040-x.

Borradaile, G., Henry, B., 1997. Tectonic applications of magnetic susceptibility and its anisotropy. Earth Sci. Rev. 42 (1), 49-93. http://doi.org/10.1016/S0012-8252(96)00044-X.

Byerly, A., Tikoff, B., Kahn, M., Jicha, B., Gaschnig, R., Fayon, A.K., 2017. Internal fabrics of the Idaho batholith, USA. Lithosphere 9 (2), 283-298. http://doi.org/10.1130/L551.1.

Caricchi, L., Burlini, L., Ulmer, P., Gerya, T., Vassalli, M., Papale, P., 2007. Non-Newtonian rheology of crystal-bearing magmas and implications for magma ascent dynamics. Earth Planet. Sci. Lett. 264 (3), 402-419. https://doi.org/10.1016/j.epsl.2007.09.032.

Castle, R.O., Lindsley, D.H., 1993. An exsolution silica-pump model for the origin of myrmekite. Contrib. Miner. Petrol. 115, 58-65. https://doi.org/10.1007/BF00712978.

Castro, A., 1987. On granitoid emplacement and related structures. A review. Geologische Rundschau 76 (1), 101-124. https://doi.org/10.1007/BF01820576.

Castro, A., 2014. The off-crust origin of granite batholiths. Geosci. Front. 5, 63-75. https://doi.org/10.1016/j.gsf.2013.06.006.

Castro, A., Díaz-Alvarado, J., Fernández, C., 2014. Fractionation and incipient self-granulitization during deep-crust emplacement of Lower Ordovician Valle Fértil batholith at the Gondwana active margin of South America. Gondwana Res. 25 (2), 685-706. https://doi.org/10.1016/j.gr.2012.08.011.

Chappell, B.W., White, A.J.R., 2001. Two contrasting granite types: 25 years later. Australian J. Earth Sci. 48 (4), 489-499. https://doi.org/10.1046/j.1440-0952.2001.00882.x. 
630 Charvet, J., 2013. The Neoproterozoic-early Paleozoic tectonic evolution of the South China 631 Block: an overview. J. Asian Earth Sci. 74, 198-209. 632 https://doi.org/10.1016/j.jseaes.2013.02.015.

633 Clemens, J.D., Mawer, C.K., 1992. Granitic magma transport by fracture propagation. 634 Tectonophysics 204 (3-4), 339-360. https://doi.org/10.1016/0040-1951(92)90316-X.

635 Collins, W.J., Richards, S.W., 2008. Geodynamic significance of S-type granites in circum-Pacific orogens. Geology 36 (7), 559-562. https://doi.org/10.1130/G24658A.1.

637 Cruden, A.R., 1988. Deformation around a rising diapir modeled by creeping flow past a sphere.

638 Tectonics 7 (5), 1091-1101. https://doi.org/10.1029/TC007i005p01091.

639 de Saint-Blanquat, M., Law, R.D., Bouchez, J.L., Morgan, S.S., 2001. Internal structure and 640 emplacement of the Papoose Flat pluton: An integrated structural, petrographic, and magnetic 641 susceptibility study. Geol. Soc. Am. Bull. 113, 976-995. https://doi.org/10.1130/0016642

643 de Saint-Blanquat, M., Habert, G., Horsman, E., Morgan, S.S., Tikoff, B., Launeau, P., Gleizes, 644 G., 2006. Mechanisms and duration of non-tectonically assisted magma emplacement in the 645 upper crust: the Black Mesa pluton, Henry Mountains, Utah. Tectonophysics 428 (1), 1-31.

647 Ding, B.H., Shi, R.D., Zhi, X.C., Zheng, L., Chen, L., 2008. Neoproterozoic ( 850 Ma) 648 subduction in the Jiangnan orogen: evidence from the SHRIMP U -Pb dating of the SSZ 649 type ophiolite in southern Anhui Province. Acta Petrol. Miner. 27 (5), 375-388. 650 https://doi.org/10.3969/j.issn.1000-6524.2008.05.001. 
651 Dunlop, D.J., 2002. Theory and application of the Day plot (Mrs/Ms versus Hcr/Hc) 2. Application

652 to data for rocks, sediments, and soils. J. Geophys. Res. Atmos. 107 (B3), EPM5-1-15.

653 https://doi.org/10.1029/2001JB000487.

654 Ernst, R.E., Baragar, W.R.A., 1992. Evidence from magnetic fabric for the flow pattern of magma

655 in the Mackenzie giant radiating dyke swarm. Nature 356, 511-513.

656 https://doi.org/10.1038/356511a0.

657 Faure, M., Pons, J., 1991. Crustal thinning recorded by the shape of the Namurian-Westphalian

658 leucogranite in the Variscan belt of the northwest Massif Central, France. Geology 19, 730-

659 733. https://doi.org/10.1130/0091-7613(1991)0192.3.CO;2.

660 Garcia, D., Pascal, M-L., Roux, J., 1996. Hydrothermal replacement of feldspars in igneous

661 enclaves of the Velay granite and the genesis of myrmekite. Euro. J. Miner. 8, 703-711.

662 https://doi.org/10.1127/ejm/8/4/0703.

663 Glazner, A.F., Bartley, J.M., 2006. Is stoping a volumetrically significant pluton emplacement process?. Geol. Soc. Am. Bull. 118 (9-10), 1185-1195.

665 Guo, L.Z., Shi, Y.S., Ma, R.S., Dong, H.G., Yang, S.F., 1989. The pre-Devonian tectonic patterns

666 and evolution of south China. J. Southeast Asian Earth Sci. 3, 87-93. 667 https://doi.org/10.1016/0743-9547(89)90012-3.

668 Horsman, E., Tikoff, B., Morgan, S., 2005. Emplacement-related fabric and multiple sheets in the 669 Maiden Creek sill, Henry Mountains, Utah, USA. J. Struct. Geol. 27 (8), 1426-1444. $670 \quad$ https://doi.org/10.1016/j.jsg.2005.03.003.

671 Hoskin, P.W.O., Schaltegger, U., 2003. The composition of zircon and igneous and metamorphic 672 petrogenesis. Rev. Miner. Geochem. 53 (1), 27-62. https://doi.org/10.2113/0530027. 
673 Hutton, D.H.W., 1988. Granite emplacement mechanisms and tectonic controls: inferences from 674 deformation studies. Earth and Environmental Science Transactions of the Royal Society of Edinburgh 79, 245-255. https://doi.org/10.1017/S0263593300014255.

$676 \mathrm{Li}, \mathrm{X} . \mathrm{H} .$, 1999. U-Pb zircon ages of granites from the southern margin of the Yangtze block:

677 timing of Neoproterozoic Jinning: orogeny in SE China and implications for Rodinia 678 assembly. Precambrian Res. 97 (1), 43-57. https://doi.org/10.1016/S0301-9268(99)00020-0.

Li, X.H., Li, Z.X., Ge, W.C., Zhou, H.W., Li, W.X., Liu, Y., Wingate, M., 2003. Neoproterozoic granitoids in South China: crustal melting above a mantle plume at ca. 825 Ma? Precambrian Res. 122, 45-83. https://doi.org/10.1016/S0301-9268(02)00207-3.

Li, Z.X., Bogdanova, S.V., Collins, A.S., Davidson, A., De Waele, B., Ernst, R.E., Fitzsimons, I.C.W., Fuck, R.A., Gladkochub, D.P., Jacobs, J., Karlstrom, K.E., Lu, S., Natapov, L.M., Pease, V., Pisarevsky, S.A., Thrane, K., Vernikovsky, V., 2008. Assembly, configuration,

Liu, H., Martelet, G., Wang, B., Erdmann, S., Chen, Y., Faure, M., Huang, F.F., Scaillet, B., Breton, and break-up history of Rodinia: A synthesis. Precambrian Res. 160, 179-210. https://doi.org/10.1016/j.precamres.2007.04.021. N., Shu, L.S., Wang, R.C., Zhu, J.C., 2018. Incremental Emplacement of the Late Jurassic Midcrustal, Lopolith-Like Qitianling Pluton, South China, Revealed by AMS and Bouguer Gravity Data. J. Geophys. Res. Solid Earth 123, 9249-9268. https://doi.org/10.1029/2018JB015761.

Liu, Y.S., Gao, S., Hu, Z.C., Gao, C.G., Zong, K.Q., Wang, D.B., 2010. Continental and oceanic crust recycling-induced melt-peridotite interactions in the trans-North China orogen: $\mathrm{U}-\mathrm{Pb}$ dating, Hf isotopes and trace elements in zircons from mantle xenoliths. J. Petrol. 51, 537571. https://doi.org/10.1093/petrology/egp082. 
Martelet, G., Perrin, J., Truffert, C., Deparis, J., 2013. Fast mapping of magnetic basement depth, structure and nature using aeromagnetic and gravity data: combined methods and their application in the Paris Basin. Geophys. Prosp. 61 (4), 857-873. https://doi.org/10.1111/1365-2478.12024.

Martín-Hernández, F., Lüneburg, C. M., Aubourg, C., Jackson, M., 2004. Magnetic fabric: methods and applications-an introduction. Geol. Soc. London 238 (1), 1-7. https://doi.org/10.1144/GSL.SP.2004.238.01.01.

Mathieu, L., De Vries, B.V.W., Holohan, E.P., Troll, V.R., 2008. Dykes, cups, saucers and sills: Analogue experiments on magma intrusion into brittle rocks. Earth Planet. Sci. Lett. 271 (1), 1-13. https://doi.org/10.1016/j.epsl.2008.02.020.

Moreira, M.A., Geoffroy, L., Pozzi, J.P., 2015. Magma flow pattern in dykes of the Azores revealed by anisotropy of magnetic susceptibility. J. Geophys. Res. Solid Earth 120, 662-690. https://doi.org/ 10.1002/2014JB010982.

Moyen, J.F., Martin, H., Jayananda, M., Auvray, B., 2003. Late Archaean granites: a typology based on the Dharwar Craton (India). Precambrian Res. 127 (1), 103-123. https://doi.org/10.1016/s0301-9268(03)00183-9.

O'Driscoll, B., Troll, V.R., Reavy, R.J., Turner, P., 2006. The Great Eucrite intrusion of Ardnamurchan, Scotland: Reevaluating the ring-dike concept. Geology 34 (3), 189-192. https://doi.org/10.1130/G22294.1.

Paterson S.R., Vernon R.H., Tobisch O.T., 1989. A review of criteria for the identification of magmatic and tectonic foliations in granitoids. J. Struct. Geol. 11 (3), 349-363. https://doi.org/10.1016/0191-8141(89)90074-6. 
718 Paterson, S.R., Pignotta, G.S., Farris, D., Memeti, V., Miller, R. B., Vernon, R. H., Žák, J., 2008.

719 Is stoping a volumetrically significant pluton emplacement process?: Discussion. Geol. Soc.

720 Am. Bull. 120 (7-8), 1075-1079. https://doi.org/10.1130/B26148.1.

721 Paterson, S.R., 2009. Magmatic tubes, pipes, troughs, diapirs, and plumes: Late-stage convective 722 instabilities resulting in compositional diversity and permeable networks in crystal-rich 723 magmas of the Tuolumne batholith, Sierra Nevada, California. Geosphere 5 (6), 496-527. 724 https://doi.org/10.1130/GES00214.1.

725 Pitcher, W.S., 1979. The nature, ascent and emplacement of granitic magmas. J. Geol. Soc. 136, $726 \quad 627-662$.

727 Rochette, P., Jackson, M., Aubourg, C., 1992. Rock magnetism and the interpretation of anisotropy 728 of magnetic susceptibility. Rev. Geophys. 30, 209-226. https://doi.org/10.1029/92rg00733.

729 Roman, A., Jaupart, C., 2016. The fate of mafic and ultramafic intrusions in the continental crust. 730 Earth Planet. Sci. Lett. 453, 131-140. https://doi.org/10.1016/j.epsl.2016.07.048.

731 Scherer, E., Munker, C., Mezger, K., 2001. Calibration of the Lutetium-Hafnium clock. Science 732

733 Shu, L.S., 2006. Pre-Devonian tectonic evolution of South China: from Cathaysia Block to 734 Caledonian period folded Orogenic Belt. Geol. J. China Uni. (Earth Sci.) 12 (4), 418-431 [in 735 Chinese with English abstract].

736 Shu, L.S., 2012. An analysis of principal features of tectonic evolution in South China Block. Geol. 737 Bull. China 31 (7), 1035-1053 [in Chinese with English abstract]. $738 \quad$ https://doi.org/10.1007/s11783-011-0280-z. 
Shu, L.S., Charvet, J., Shi, Y.S., Faure, M., Cluzel, D., Guo, L.Z., 1991. Structural analysis of the Nanchang-Wanzai sinistral ductile shear zone (Jiangnan region, South China). J. Southeast Asian Earth Sci. 6 (1), 13-23. https://doi.org/10.1016/0743-9547(91)90091-B.

Shu, L.S., Zhou, G.Q., Shi, Y.S., Yin, J., 1994. Study on the high pressure metamorphic blueschist

Shu, L.S., Faure, M., Jiang, S.Y., Yang, Q., Wang, Y.J., 2006. SHRIMP zircon U-Pb age, litho and biostratigraphic analyses of the Huaiyu Domain in South China-Evidence for a Neoproterozoic orogen, not Late Paleozoic-Early Mesozoic collision. Episodes 29 (4), 244 252. https://doi.org/10.1007/s00254-006-0521-9.

Shu, L.S., Faure, M., Yu, J.H., Jahn, B.M., 2011. Geochronological and geochemical features of the Cathaysia block (South China): New evidence for the Neoproterozoic breakup of Rodinia. Precambrian Res. 187 (3-4), 263-276. https://doi.org/10.1016/j.precamres.2011.03.003.

Shu, L.S., Jahn, B.M., Charvet, J., Santosh, M., Wang, B., Xu, X.S., Jiang, S.Y., 2014. Early Paleozoic depositional environment and intracontinental orogeny in the Cathaysia Block (South China): implications from stratigraphic, structural, geochemical and geochronologic evidence. Am. J. Sci. 314 (1), 154-186. https://doi.org/10.2475/01.2014.05.

Shu, L.S., Wang, B., Cawood, P.A., Santosh, M., Xu, Z.Q., (2015). Early Paleozoic and Early Mesozoic intraplate tectonic and magmatic events in the Cathaysia Block, South China. Tectonics 34, 1600-1621. https://doi.org/10.1002/2015tc003835.

Shu, L.S., Wang, J.Q., Yao, J.L., 2019. Tectonic evolution of the eastern Jiangnan region, South China: New findings and implications on the assembly of the Rodinia supercontinent. Precambrian Res. 322, 42-65. https://doi.org/ 10.1016/j.precamres.2018.12.007. 
762 Song, M.J., Shu, L.S., Santosh, M., Li, J.Y., 2015. Late Early Paleozoic and Early Mesozoic 763 intracontinental orogeny in the South China Craton: Geochronological and geochemical 764 evidence. Lithos 232, 360-374. https://doi.org/10.1016/j.lithos.2015.06.019.

765 Stevenson, C.T., Owens, W.H., Hutton, D.H., Hood, D.N., Meighan, I.G., 2007. Laccolithic, as 766 opposed to cauldron subsidence, emplacement of the Eastern Mourne pluton, N. Ireland: 767 evidence from anisotropy of magnetic susceptibility. J. Geol. Soc. 164 (1), 99-110. 768 https://doi.org/10.1144/0016076492006-008.

Sun, J.J., Shu, L.S., Santosh, M., Wang, L.S., 2017. Neoproterozoic tectonic evolution of the Jiuling terrane in the central Jiangnan orogenic belt (South China): Constraints from $\begin{array}{lllll}\text { magmatic } & \text { suites. } & \text { Precambrian } & \text { Res. }\end{array}$ https://doi.org/10.1016/j.precamres.2017.10.003.

Tarling, D., Hrouda, F., 1993. Magnetic anisotropy of rocks. Springer Science \& Business Media. Wang, J., Li, Z.X., 2003. History of Neoproterozoic rift basins in South China: implications for Rodinia break-up. Precambrian Res. 122, 141-158. https://doi.org/10.1016/S03019268(02)00209-7.

Wang, W., Zhou, M.F., Yan, D.P., Li, J.W., 2012. Depositional age, provenance, and tectonic setting of the Neoproterozoic sibao group, southeastern Yangtze block, South China. Precambrian Res. 192 (1), 107-124. https://doi.org/10.1016/j.precamres.2011.10.010. Wang, X.L., Zhou, J.C., Qiu, J.S., Zhang, W.L., Liu, X.M., Zhang, G.L., 2006. LA-ICP-MS U$\mathrm{Pb}$ zircon geochronology of the Neoproterozoic igneous rocks from Northern Guangxi, South China: implications for petrogenesis and tectonic evolution. Precambrian Res. 145 (1-2), 111-130. https://doi.org/10.1016/j.precamres.2005.11.014. 
Wang, X.L., Zhou, J.C., Griffin, W.L., Wang, R.C., Qiu, J.S., O’Reilly, S.Y., Xu, X.S., Liu, X.M., Zhang, G.L., 2007. Detrital zircon geochronology of Precambrian basement sequences in the Jiangnan orogen: dating the assembly of the Yangtze and Cathaysia Blocks. Precambrian Res. 159 (1-2), 117-131. https://doi.org/10.1016/j.precamres.2007.06.005.

Wang, X.L., Zhou, J.C., Griffin, W.L., Zhao, G.C., Yu, J.H., Qiu, J.S., Zhang, Y.J., Xing, G.F., 2014a. Geochemical zonation across a Neoproterozoic orogenic belt: Isotopic evidence from

Wang, Y.J., Wu, C.M., Zhang, A.M., Fan, W.M., Zhang, Y.H., Zhang, Y.Z., Peng, T.P., Ying, 154-171. https://doi.org/10.1016/j.precamres.2013.12.023.

C.Q., 2012b. Kwangsian and Indosinian reworking of the eastern South China Block: constraints on zircon $\mathrm{U}-\mathrm{Pb}$ geochronology and metamorphism of amphibolites and granulites. Lithos 150, 227-242. https://doi.org/10.1016/j.lithos.2012.04.022.

Wang, Y.J., Zhang, A.M., Cawood, P.A., Fan, W.M., Xu, J.F., Zhang, G.W., Zhang, Y.Z., 2013. Geochronological, geochemical and $\mathrm{Nd}-\mathrm{Hf}-\mathrm{Os}$ isotopic finger printing of an early Neoproterozoic arc-back-arc system in South China and its accretionary assembly along the margin of Rodinia. Precambrian $\quad$ Res. 231, 343-371. https://doi.org/10.1016/j.precamres.2013.03.020.

Wang, Y.J., Zhang, Y.Z., Fan, W.M., Geng, H.Y., Zou, H.P., Bi, X.W., 2014b. Early Neoproterozoic accretionary assemblage in the Cathaysia block: geochronological, Lu-Hf isotopic and geochemical evidence from granitoid gneisses. Precambrian Res. 249, 144-161. https://doi.org/10.1016/j.precamres.2014.05.003.

Wei, W., Chen, Y., Faure, M., Shi, Y.H., Martelet, G., Hou, Q.L., Lin, W., Breton, N., Wang, Q.C., 2014. A multidisciplinary study on the emplacement mechanism of the Qingyang-Jiuhua 
massif in southeast China and its tectonic bearings. Part I: Structural geology, AMS and paleomagnetism. J. Asian Earth Sci. 86, 76-93. https://doi.org/10.1016/j.jseaes.2013.06.003.

Wei, W., Chen, Y., Faure, M., Martelet, G., Lin, W., Wang, Q. C., Yan, Q.R., Hou, Q.L., 2016. An early extensional event of the South China Block during the Late Mesozoic recorded by

(Hunan,

SE

China).

Tectonophysics

672-673,

$50-67$. https://doi.org/10.1016/j.tecto.2016.01.028.

Wu, R.X., Zheng, Y.F., Wu, Y.B., Zhao, Z.F., Zhang, S.B., Liu, X.M., Wu, F.Y., 2006. Reworking of juvenile crust: Element and isotope evidence from Neoproterozoic granodiorite in South China. Precambrian Res. 146, 179-212. https://doi.org/10.1016/j.precamres.2006.01.012.

Xia, Y., Xu, X.S., Niu, Y.L., Liu, L., 2018. Neoproterozoic amalgamation between Yangtze and Cathaysia blocks: The magmatism in various tectonic settings and continent-arc-continent collision. Precambrian Res. 309, 56-87. https://doi.org/10.1016/j.precamres.2017.02.020.

Xin, Y., Li, J., Dong, S., Zhang, Y., Wang, W., Sun, H., 2017. Neoproterozoic post-collisional extension of the central Jiangnan Orogen: Geochemical, geochronological, and $\mathrm{Lu}-\mathrm{Hf}$ isotopic constraints from the ca. 820-800 Ma magmatic rocks. Precambrian Res. 294, 91110. https://doi.org/10.1016/j.precamres.2017.03.018.

Xue, H.M., Ma, F., Song, Y.Q., Xie, Y.P., 2010. Geochronology and geochemisty of the Neoproterozoic granitoid association from eastern segment of the Jiangnan orogen, China: Constraints on the timing and process of amalgamation between the Yangtze and Cathaysia blocks [in Chinese with English abstract]. Acta Geologica Sinica 26, 3215-3244.

828 Yan, C.L., Shu, L.S., Faure, M., Chen, Y., Li, C., 2017. Early Paleozoic intracontinental orogeny in the Yunkai domain, South China Block: New insights from field observations, zircon U- 
$\mathrm{Pb}$ geochronological and geochemical investigations. Lithos 268-271, 320-333. https://doi.org/10.1016/j.lithos.2016.11.013.

832 Yan, C.L., Shu, L.S., Faure, M., Chen, Y., Huang, R.B., 2019. Time constraints on the closure of 833 the Paleo-South China Ocean and the Neoproterozoic assembly of the Yangtze and Cathaysia 834 blocks: Insight from new detrital zircon analyses. Gondwana Res. 73, 175-189. 835 https://doi.org/10.1016/j.gr.2019.03.018.

Yao, J.L., Shu, L.S., M. Santosh, Zhao, G.C., 2014a. Neoproterozoic arc-related mafic-ultramafic rocks and syn-collision granite from the western segment of the Jiangnan Orogen, South China: Constraints on the Neoproterozoic assembly of the Yangtze and Cathaysia Blocks.

Yao, J.L, Shu, L.S., Santosh, M., Zhao, G.C., 2014b. Neoproterozoic arc-trench system and Precambrian Res. 243, 39-62. https://doi.org/10.1016/j.precamres.2013.12.027.

Yao, J.L, Cawood, P.A., Shu, L.S., Zhao, G.C., 2019. Jiangnan Orogen, South China: A 970breakup of the South China Craton: Constraints from N-MORB type and arc-related mafic $820 \mathrm{Ma}$ Rodinia margin accretionary belt. Earth Sci. Rev. 196, 102872.

847 Žák, J., Paterson, S.R., Memeti, V., 2007. Four magmatic fabrics in the Tuolumne batholith, rocks, and anorogenic granite in the Jiangnan orogenic belt. Precambrian Res. 247, 187-207. https://doi.org/10.1016/j.precamres.2014.04.008. https://doi.org/10.1016/j.earscirev.2019.05.016. central Sierra Nevada, California (USA): implications for interpreting fabric patterns in plutons and evolution of magma chambers in the upper crust. Geol. Soc. Am. Bull. 119 (12), 184-201. https://doi.org/10.1130/B25773.1.

Zhang, Y.Z., Wang, Y.J., Geng, H.Y., Zhang, Y.H., Fan, W.M., Zhong, H., 2013. Early 852 Neoproterozoic ( $850 \mathrm{Ma}$ ) back-arc basin in the Central Jiangnan Orogen (Eastern South 
China): geochronological and petrogenetic constraints from meta-basalts. Precambrian Res. 231, 325-342. https://doi.org/10.1016/j.precamres.2013.03.016.

Zhang, Y.Z., Wang, Y.J., 2016. Early Neoproterozoic ( 840 Ma) arc magmatism:

856 geochronological and geochemical constraints on the meta-basites in the Central Jiangnan

Zhong, Y.F., Ma, C.Q., She, Z.B., Lin, G.C., Xu, H.J., Wang, R.J., Yang, K.G., Liu, Q., 2005. SHRIMP U-Pb zircon geochronology of the Jiuling granitic complex batholith in Jiangxi Province [in Chinese with English abstract]. Earth Science-Journal of China University of

Zhou, J.C., Wang, X.L., Qiu, J.S., Gao, J.F., 2004. Geochemistry of meso- and Neoproterozoic mafic-ultramafic rocks from northern Guangxi, China: arc or plume magmatism?. Geochem.

\section{Figure captions}

870 Figure 1. Simplified tectonic map of the South China Block.

871 Figure 2. Geological sketch map of the Sanfang-Yuanbaoshan area with a NW-SE cross-section. according to the field observations, however, the deep structure of the profile is inferred from the gravity modeling. Note that the vertical scale is exaggerated in order to show more details. 
876 Figure 3. Representative field photos in the Sanfang-Yuanbaoshan area, with the geographic localities in the sketch map. (A) Massive granite in the Sanfang pluton; (B) Massive granite in the Yuanbaoshan pluton; (C) Foliated porphyritic granite with the top-to-theW kinematics; (D) Hornfel between the Sanfang pluton and Sibao group; (E) Sibao group with vertical beddings; (F) Sibao group with moderate inclination; (G) Sigmoid quartz vein indicates a top-to-the-W kinematic; (H) Recumbent folding of the Sibao group, with the axis gently plunging to the north; (I) E-W directed lineations in the Sibao group; (J) Mylonite on the roof of the Yuanbaoshan pluton; (K) Eastward kinematics in the Sibao group.

Figure 4. Microphotographs with the representative features of the granites and country rocks in the Sanfang-Yuanbaoshan area. (A and B) Microphotographs of undeformed granites with crossed polarized light; (C) Undeformed granite in the Yuanbaoshan pluton; (D) Highly deformed granites showing orientated quartz and interstitial myrmekite, crossed polarized light; (E) Mica fish in the highly deformed granites showing top-to-the-W kinematics, crossed polarized light; (F) Deformed granite in the Yuanbaoshan pluton; (G) Microphotographs in reflected light of the Sibao group with top-to-the-W kinematics; (H) Sigma structure and pressure shadows in the Sibao group with top-tothe-W kinematics, crossed polarized light.

Figure 5. The Cathodoluminescence, $\mathrm{U}-\mathrm{Pb}$ ages and epsilon $\mathrm{Hf}(\mathrm{t})$ results of the granite samples of A37 and B13 from the Sanfang and Yuanbaoshan plutons, respectively. (A and B) Cathodoluminescence (CL) images of zircons from two samples, with analyzed locations and $\mathrm{U}-\mathrm{Pb}$ ages; (C) Plot of epsilon $\mathrm{Hf}(\mathrm{t})$ versus $\mathrm{U}-\mathrm{Pb}$ age of zircons from the Sanfang pluton; (D) $\mathrm{U}-\mathrm{Pb}$ concordia plots for the zircons from Sanfang granite; (E) 
Enlarged interval of the concentrated ages in the D; $(F)$ The average of the ages showed in the $\mathrm{E} ;(\mathrm{G}) \mathrm{U}-\mathrm{Pb}$ concordia plots for the zircons from Yuanbaoshan granite; $(\mathrm{H})$ Enlarged interval of the concentrated ages in the G; (I) The average of the ages showed in the $\mathrm{H}$.

Figure 6. Magnetic mineralogic analyse of the granites in the Sanfang pluton. (A) Hysteresis loop Thermomagnetic curves; (D) Scanning Electron Microscope imagines of the biotite grains; (E) Day-plot of hysteresis parameters. Abbreviation: Magnetic coercivity of the measured sample (Hc); Coercivity of magnetic remanence (Hcr); Multidomain (MD);

Figure 7. Sketch map with the sampling sites and AMS results for each site.

911 Figure 8. Magnetic parameters of the granites of the Sanfang-Yuanbaoshan plutons. (A) Distribution of the Km; (B) Scatter plot of the Km versus PJ; (C) Scatter plot of the Km versus elevation; (D) Scatter plot of the PJ and elevation with a positive correlation; (E) Scatter plot of the $\mathrm{T}$ and elevation with a positive correlation; (F) Scatter plot of the $\mathrm{T}$ and PJ with a positive correlation. All the data are site-mean value for each sampling site; (G) Partition of the two plutons according to the integrated criteria of field observations, features of the magnetic foliations and lineations and PJ values; $(\mathrm{H}) \mathrm{A}$ sampling section showing generally positive correlation between the PJ value and elevation. Abbreviation: Bulk magnetic susceptibility (Km); Anisotropy degree of the magnetic susceptibility (PJ); Shape parameter (T). 
921 Figure 9. A synthetic distribution map of the magnetic foliations and lineations in the Sanfang and Yuanbaoshan granitic plutons. The black symbols represent the sub-solidus fabrics, whereas the white ones correspond to post-solidus fabrics.

924 Figure 10. The residual Bouguer gravity anomaly map of the Sanfang-Yuanbaoshan area with five interpreted profiles.

926 Figure 11. 3-D model for the emplacement mechanism of the Sanfang and Yuanbaoshan plutons in ca. 830 Ma ago.

\section{$928 \quad$ Figures}

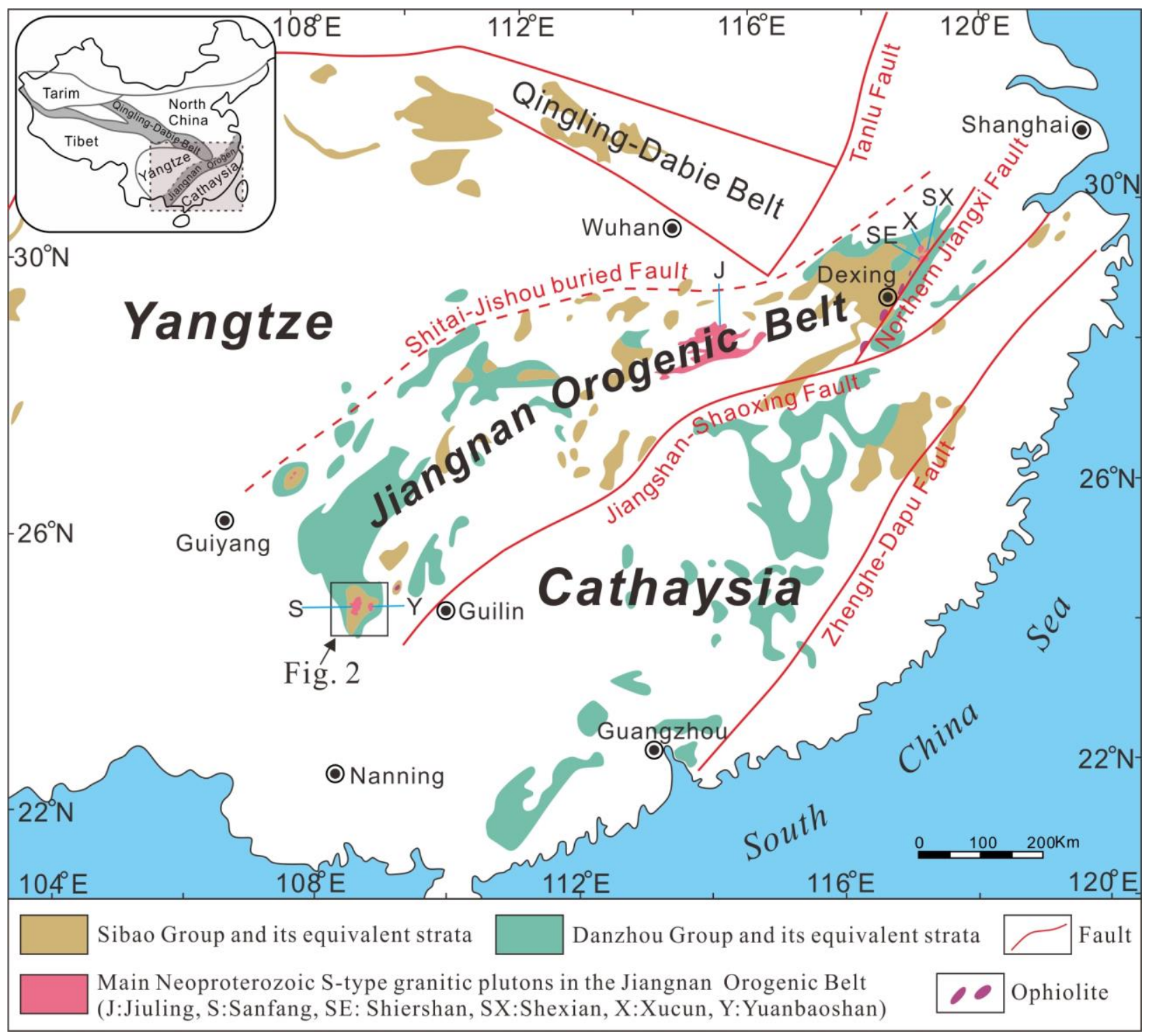



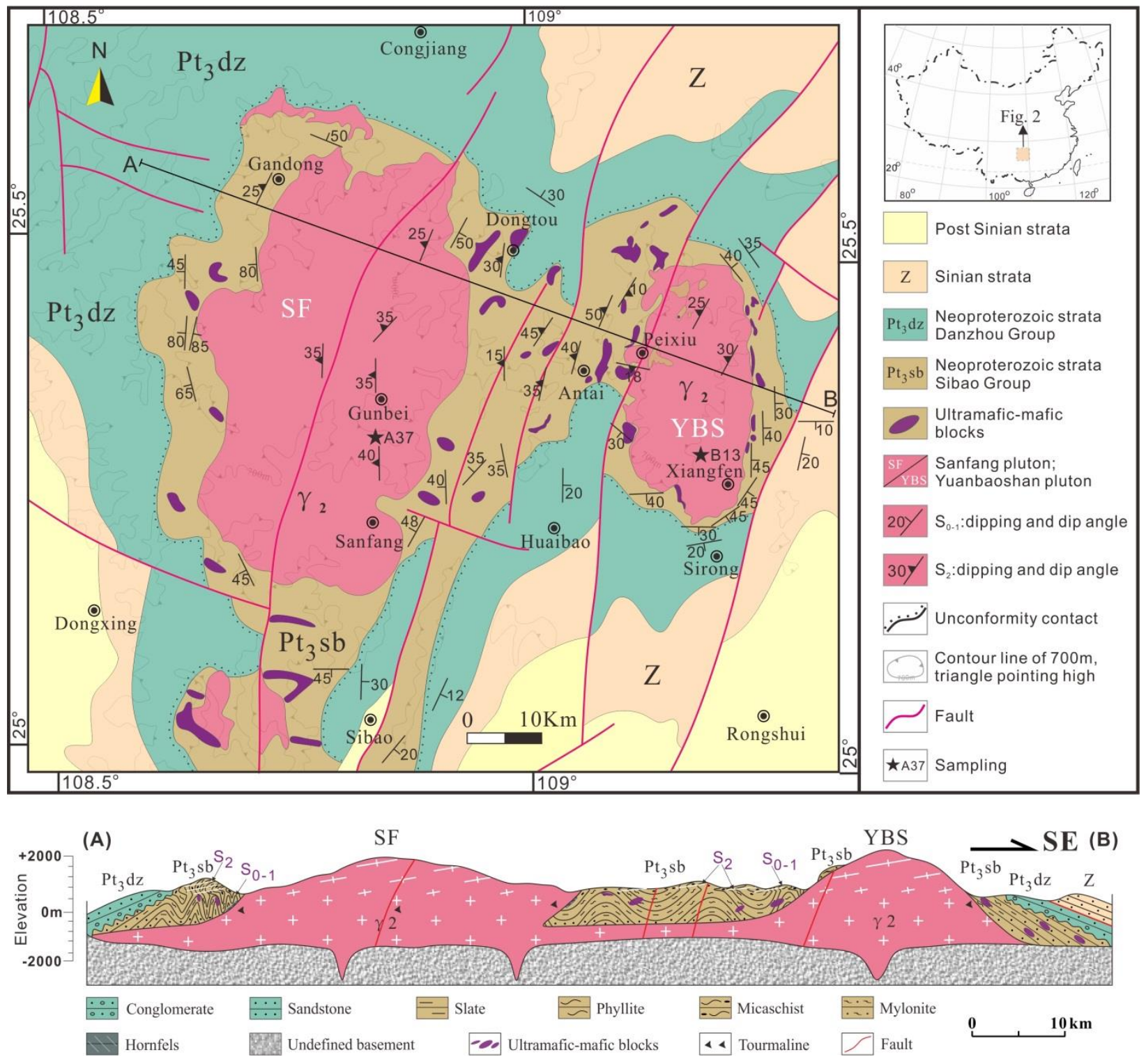

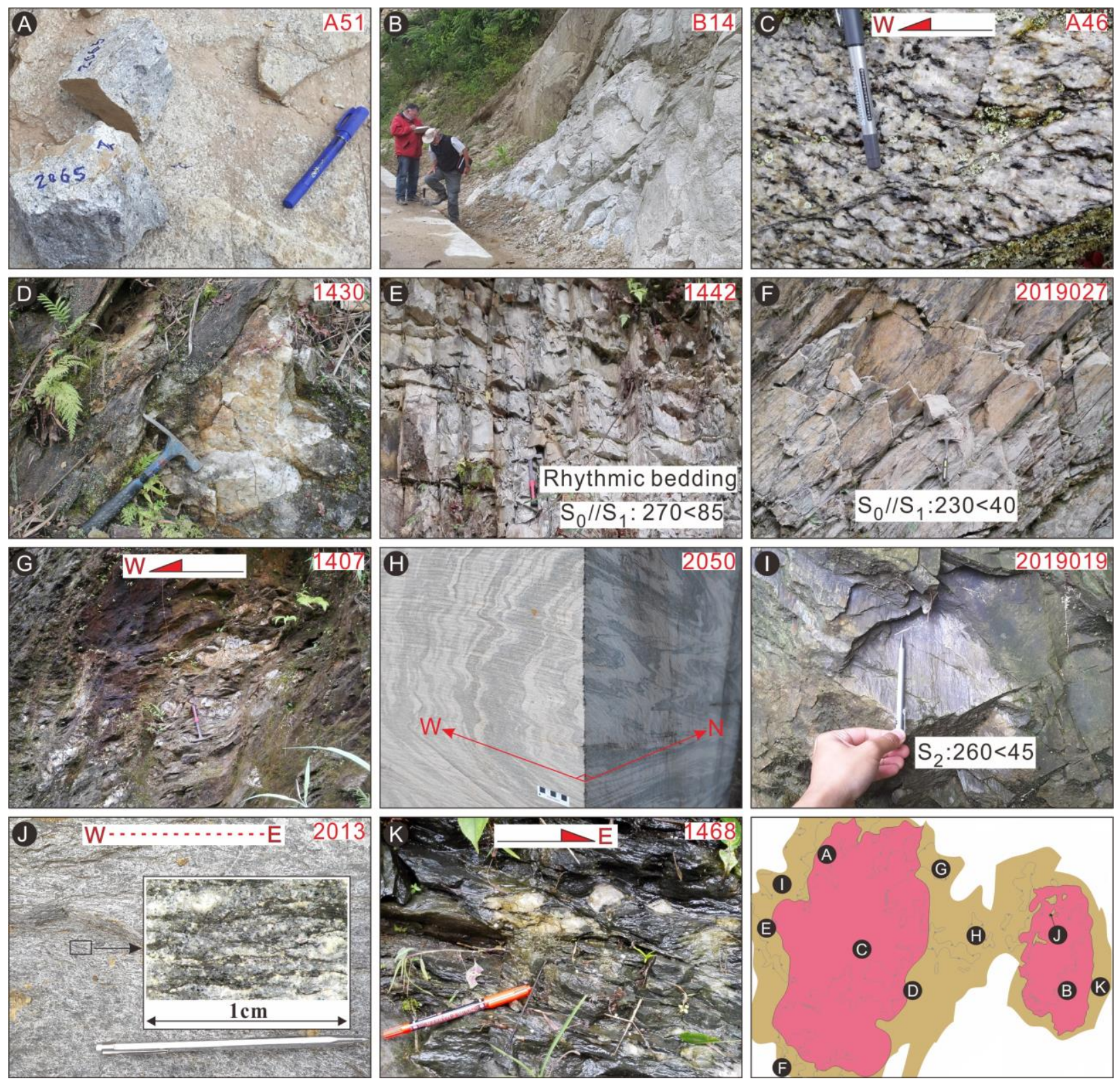

934

Figure 3 

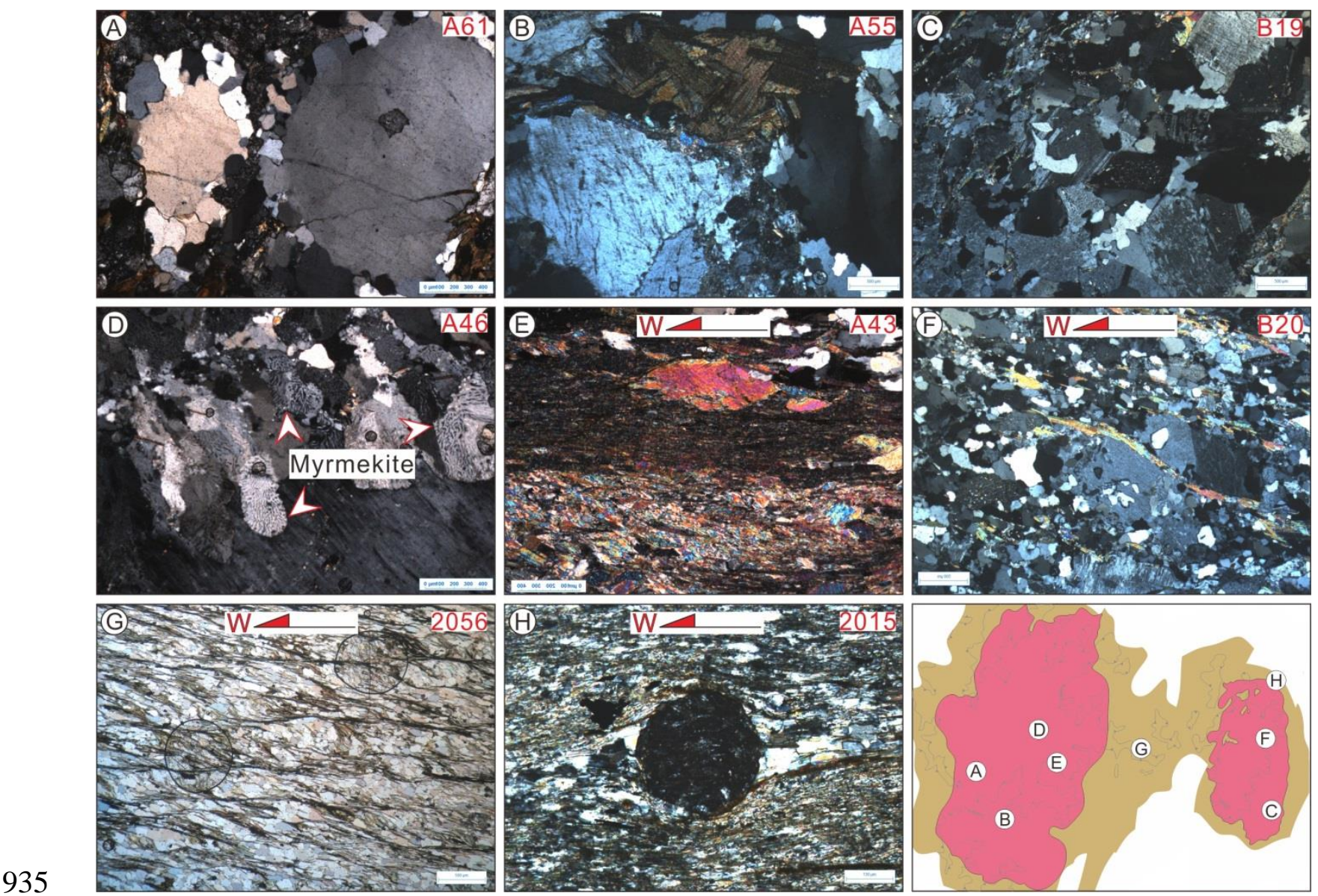

Figure 4 

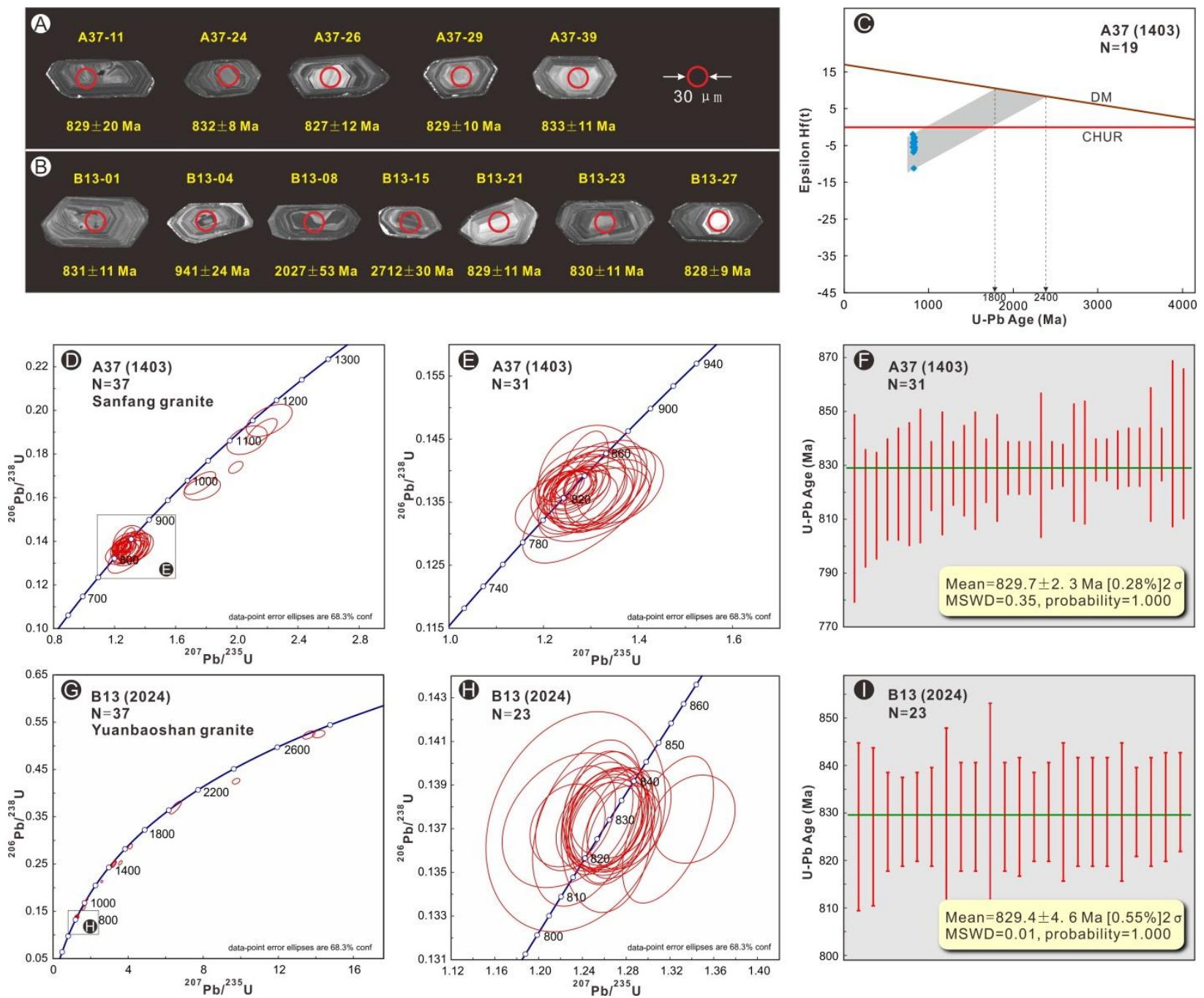

Figure 5 

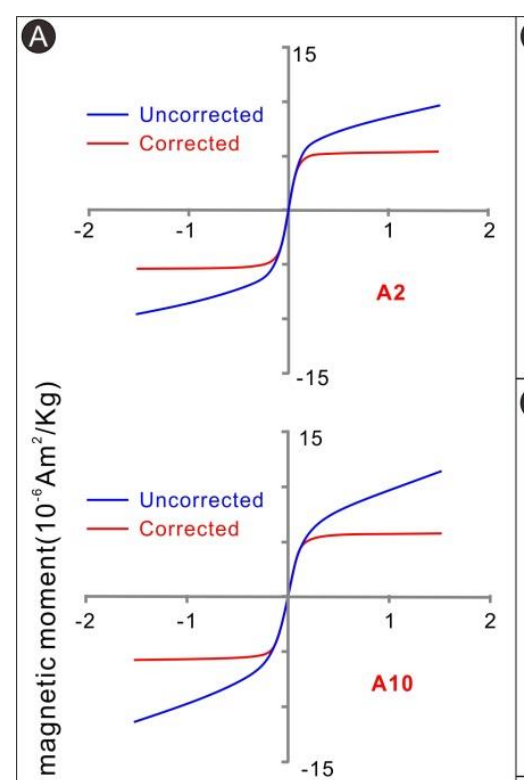

939

940

Applied magnetic field ( $T$ )

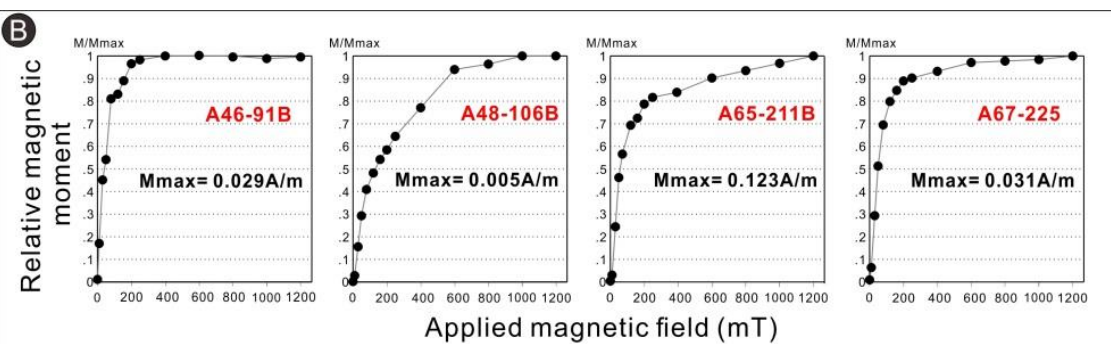

C

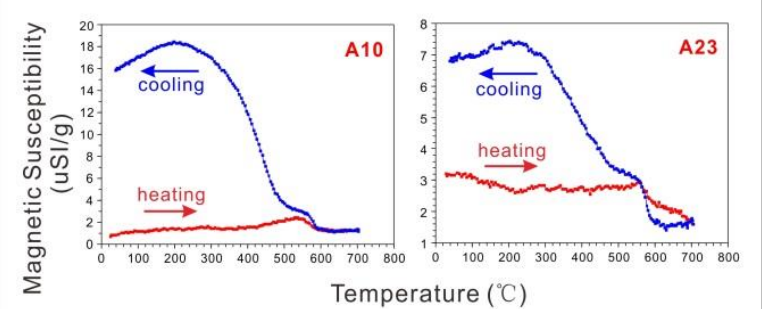

D
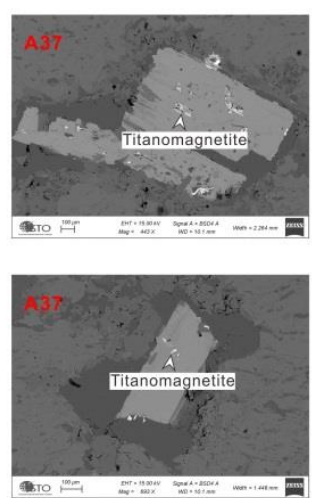

E

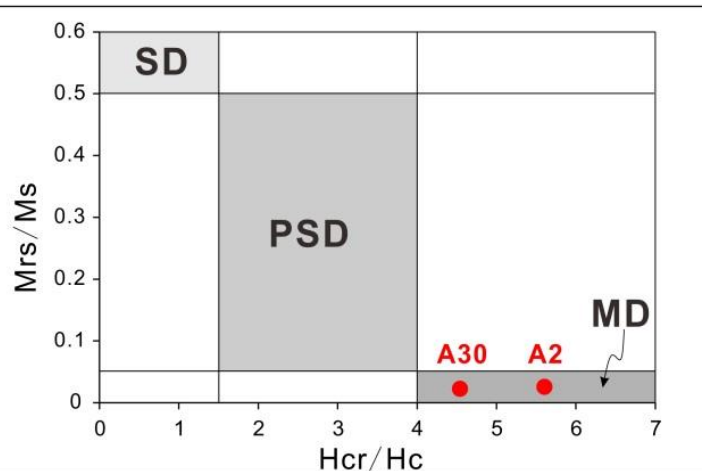
$\mathrm{Hcr} / \mathrm{Hc}$

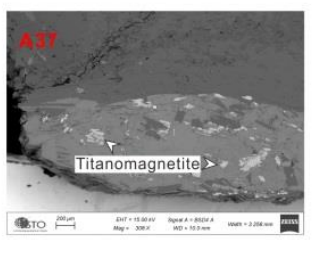

Figure 6 


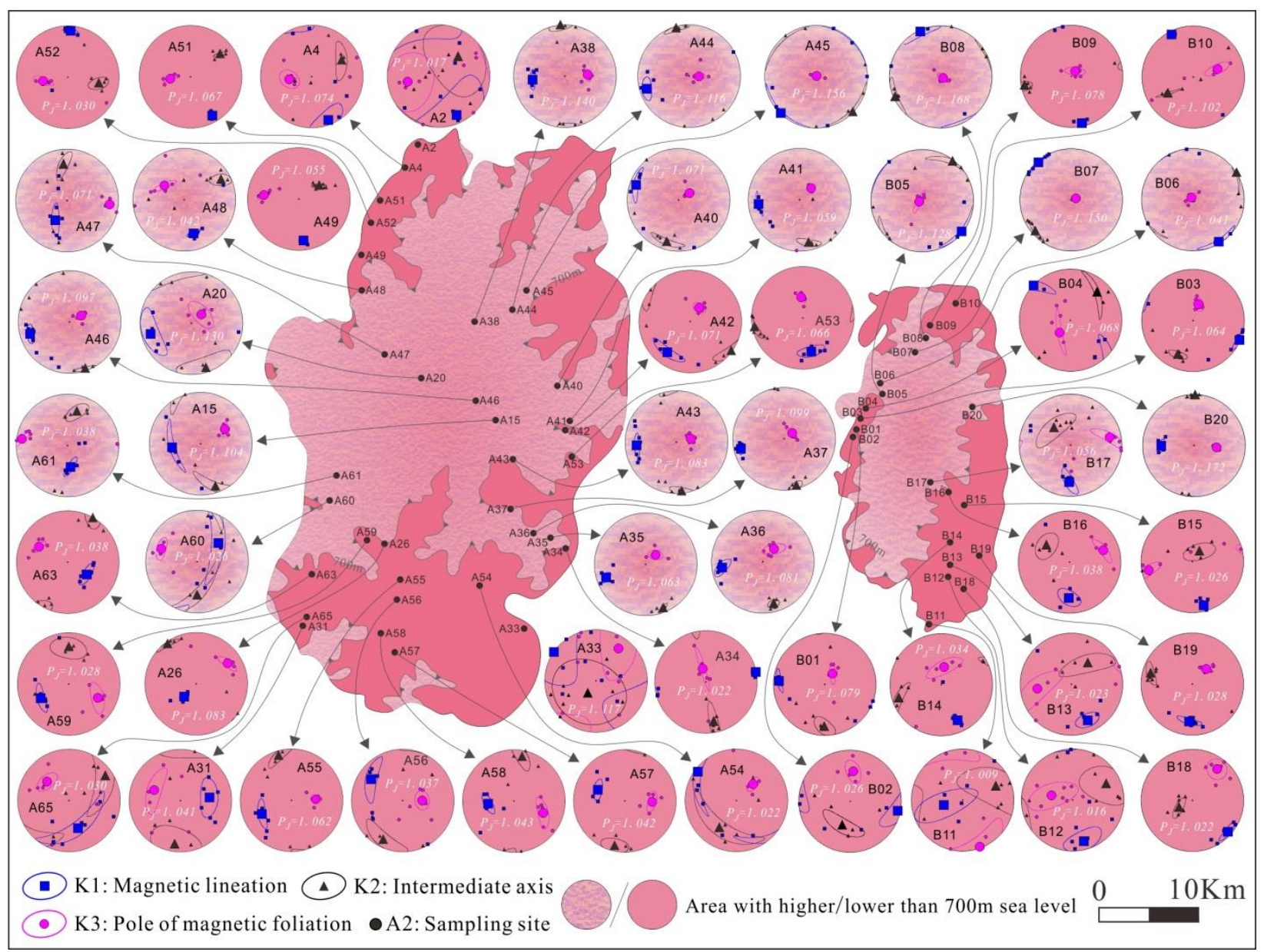




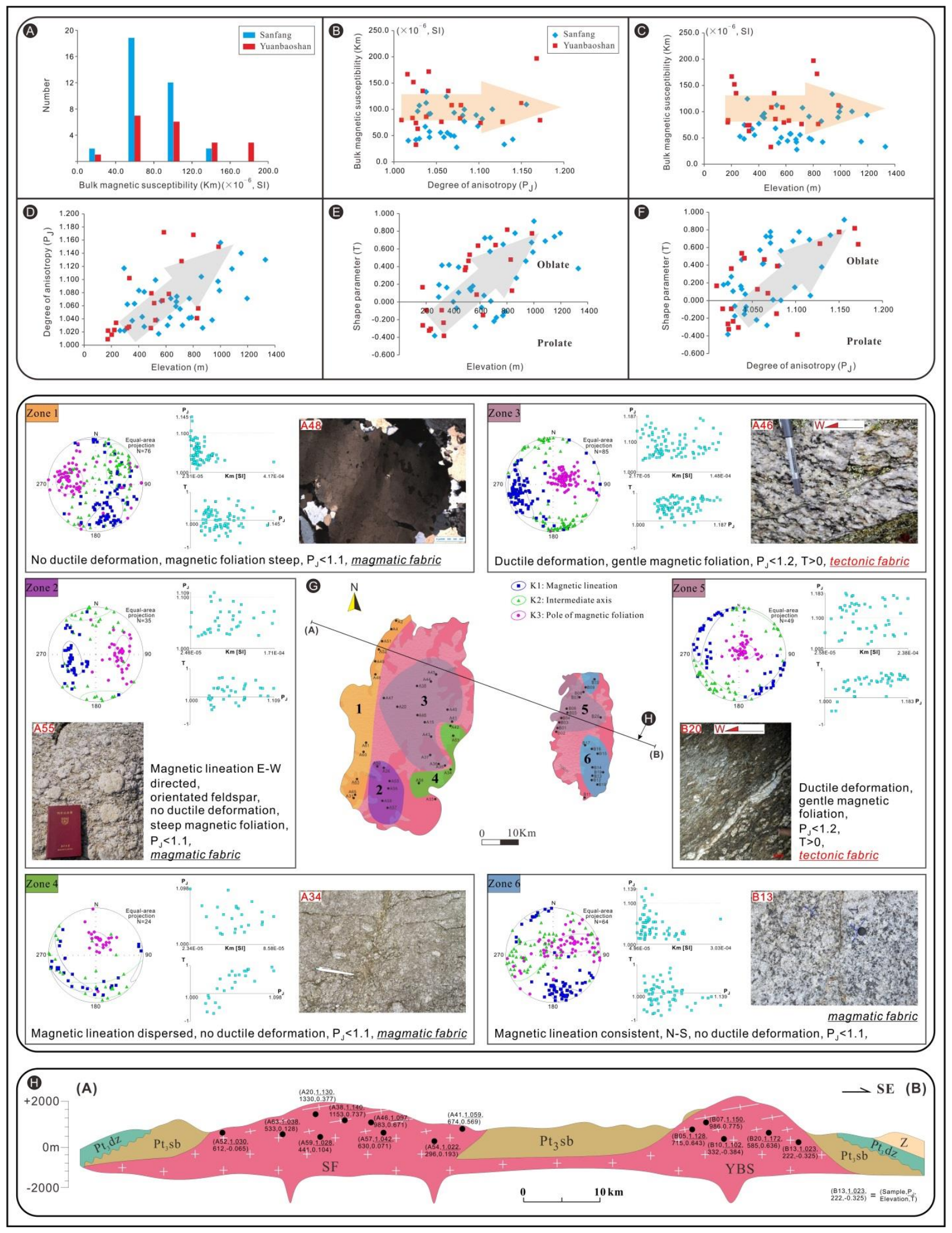




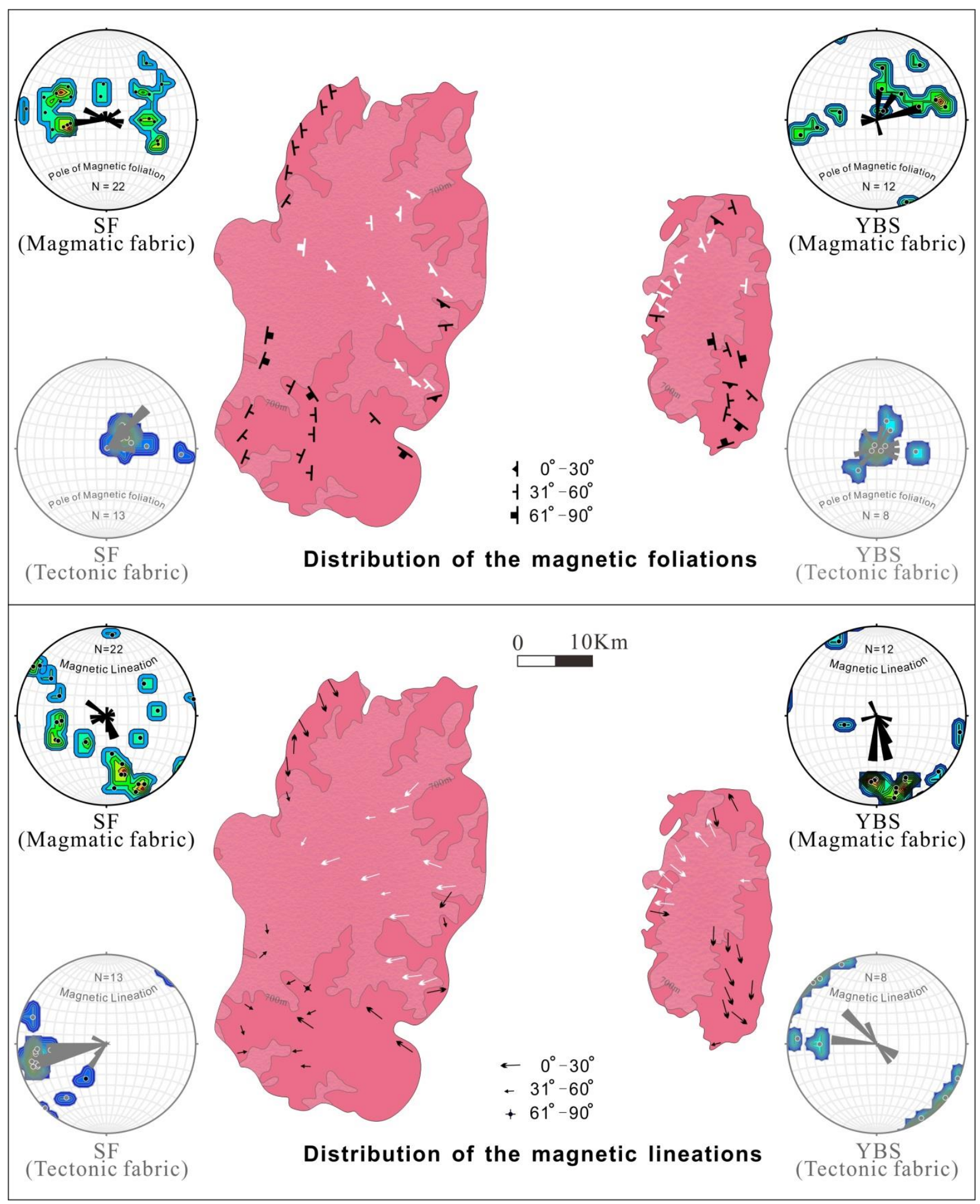

Figure 9 


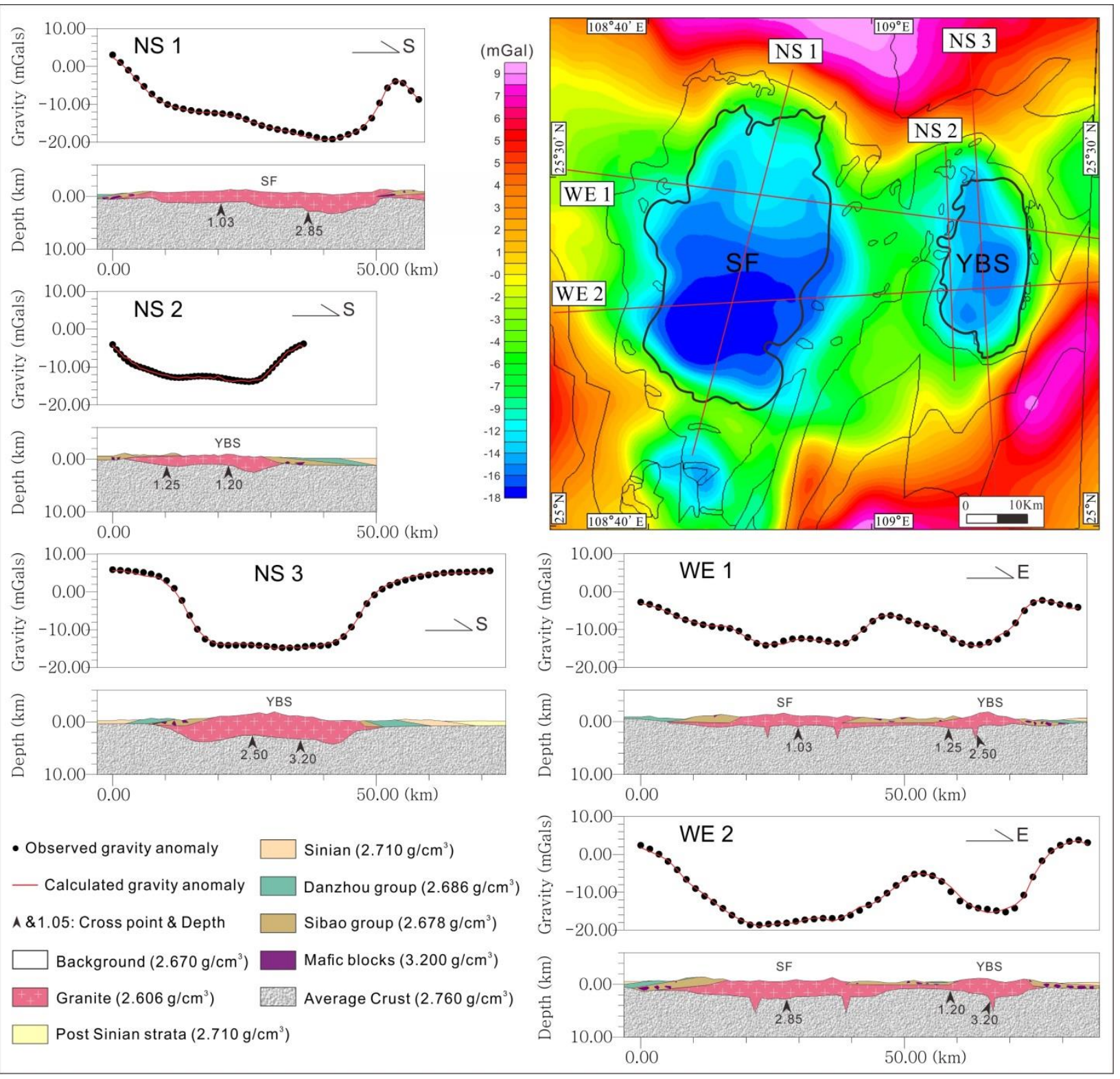




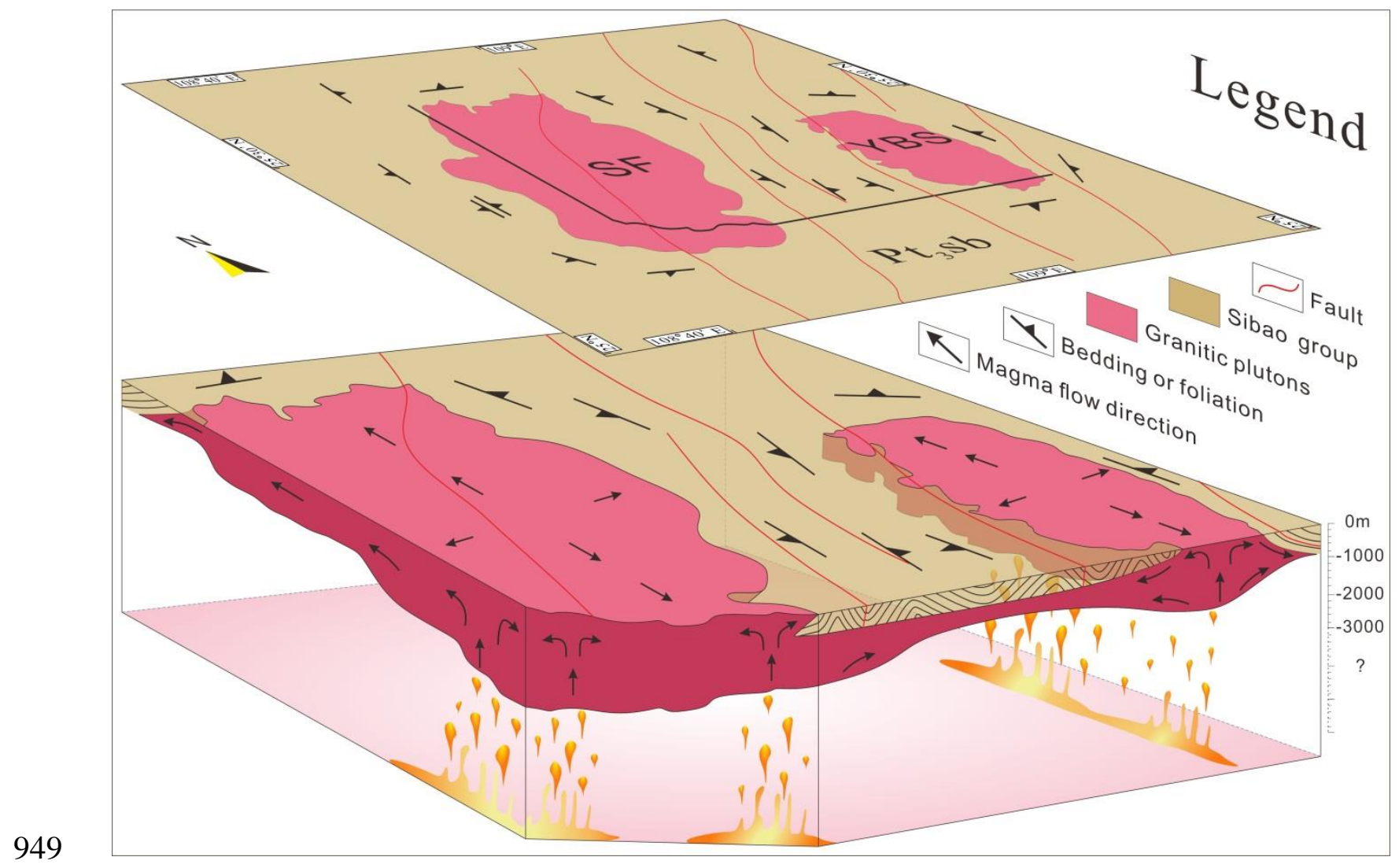

Figure 11 
Tables

\begin{tabular}{|c|c|c|c|c|c|c|c|c|c|c|c|c|c|c|}
\hline \multirow{3}{*}{$\begin{array}{c}\text { Analysi } \\
s\end{array}$} & \multirow{3}{*}{$\begin{array}{c}207 P b / 206 P \\
b\end{array}$} & \multicolumn{4}{|c|}{ CORRECTED RATIOS } & \multicolumn{7}{|c|}{ CORRECTED AGES $(\mathrm{Ma})$} & \multirow{3}{*}{$\begin{array}{c}\text { concordanc } \\
e\end{array}$} & \multirow{3}{*}{$\begin{array}{c}T h / L \\
\text { ratio } \\
s\end{array}$} \\
\hline & & \multirow[b]{2}{*}{$1 \sigma$} & $\begin{array}{c}207 P b / 235 \\
U\end{array}$ & & \multirow[t]{2}{*}{$\begin{array}{c}206 \mathrm{~Pb} / 238 \\
U\end{array}$} & \multirow{2}{*}{\multicolumn{2}{|c|}{$\begin{array}{c}207 P b / 206 P \\
b\end{array}$}} & \multirow{2}{*}{\multicolumn{2}{|c|}{$\begin{array}{c}207 P b / 235 \\
U\end{array}$}} & \multicolumn{3}{|c|}{$\begin{array}{c}206 \mathrm{~Pb} / 238 \\
U\end{array}$} & & \\
\hline & & & & $1 \sigma$ & & & & & & $\begin{array}{l}1 \\
\sigma\end{array}$ & & $\begin{array}{l}1 \\
\sigma\end{array}$ & & \\
\hline \multicolumn{15}{|c|}{ Sample A37 (1403) } \\
\hline $1403-1$ & 0.064170 & $\begin{array}{c}0.00337 \\
0\end{array}$ & 1.248450 & $\begin{array}{c}0.07149 \\
0\end{array}$ & 0.134730 & $\begin{array}{c}0.00351 \\
0\end{array}$ & 747 & $\begin{array}{c}11 \\
4\end{array}$ & 823 & $\begin{array}{l}3 \\
2\end{array}$ & 815 & $\begin{array}{l}2 \\
0\end{array}$ & $99 \%$ & 0.94 \\
\hline $1403-2$ & 0.066760 & $\begin{array}{c}0.00355 \\
0\end{array}$ & 1.296120 & $\begin{array}{c}0.09280 \\
0\end{array}$ & 0.134580 & $\begin{array}{c}0.00609 \\
0\end{array}$ & 830 & $\begin{array}{c}11 \\
4\end{array}$ & 844 & $\begin{array}{l}4 \\
1\end{array}$ & 814 & $\begin{array}{l}3 \\
5\end{array}$ & $96 \%$ & 0.24 \\
\hline $1403-3$ & 0.067440 & $\begin{array}{c}0.00349 \\
0\end{array}$ & 1.306550 & $\begin{array}{c}0.07720 \\
0\end{array}$ & 0.134610 & $\begin{array}{c}0.00385 \\
0\end{array}$ & 851 & $\begin{array}{c}11 \\
0\end{array}$ & 849 & $\begin{array}{l}3 \\
4\end{array}$ & 814 & $\begin{array}{l}2 \\
2\end{array}$ & $95 \%$ & 0.27 \\
\hline $1403-4$ & 0.075440 & $\begin{array}{c}0.00315 \\
0\end{array}$ & 1.773600 & $\begin{array}{c}0.07894 \\
0\end{array}$ & 0.164030 & $\begin{array}{c}0.00335 \\
0\end{array}$ & 1080 & 86 & 1036 & $\begin{array}{l}2 \\
9\end{array}$ & 979 & $\begin{array}{l}1 \\
9\end{array}$ & $94 \%$ & 0.15 \\
\hline $1403-5$ & 0.068760 & $\begin{array}{c}0.00293 \\
0\end{array}$ & 1.337000 & $\begin{array}{c}0.05990 \\
0\end{array}$ & 0.136220 & $\begin{array}{c}0.00367 \\
0\end{array}$ & 892 & 90 & 862 & $\begin{array}{l}2 \\
6\end{array}$ & 823 & $\begin{array}{l}2 \\
1\end{array}$ & $95 \%$ & 0.37 \\
\hline $1403-6$ & 0.079070 & $\begin{array}{c}0.00305 \\
0\end{array}$ & 2.212030 & $\begin{array}{c}0.09938 \\
0\end{array}$ & 0.195370 & $\begin{array}{c}0.00488 \\
0\end{array}$ & 1174 & 78 & 1185 & $\begin{array}{l}3 \\
1\end{array}$ & 1150 & $\begin{array}{l}2 \\
6\end{array}$ & $97 \%$ & 0.56 \\
\hline $1403-7$ & 0.065360 & $\begin{array}{c}0.00255 \\
0\end{array}$ & 1.264680 & $\begin{array}{c}0.05093 \\
0\end{array}$ & 0.136980 & $\begin{array}{c}0.00301 \\
0\end{array}$ & 786 & 84 & 830 & $\begin{array}{l}2 \\
3\end{array}$ & 828 & $\begin{array}{l}1 \\
7\end{array}$ & $99 \%$ & 0.43 \\
\hline $1403-9$ & 0.078520 & $\begin{array}{c}0.00310 \\
0\end{array}$ & 2.067010 & $\begin{array}{c}0.08720 \\
0\end{array}$ & 0.186330 & $\begin{array}{c}0.00433 \\
0\end{array}$ & 1160 & 80 & 1138 & $\begin{array}{l}2 \\
9\end{array}$ & 1101 & $\begin{array}{l}2 \\
4\end{array}$ & $96 \%$ & 0.40 \\
\hline $\begin{array}{c}1403- \\
10\end{array}$ & 0.067610 & $\begin{array}{c}0.00318 \\
0\end{array}$ & 1.294370 & $\begin{array}{c}0.06193 \\
0\end{array}$ & 0.135810 & $\begin{array}{c}0.00329 \\
0\end{array}$ & 856 & $\begin{array}{c}10 \\
0\end{array}$ & 843 & $\begin{array}{l}2 \\
7\end{array}$ & 821 & $\begin{array}{l}1 \\
9\end{array}$ & $97 \%$ & 0.43 \\
\hline $\begin{array}{c}1403- \\
11\end{array}$ & 0.066860 & $\begin{array}{c}0.00324 \\
0\end{array}$ & 1.283580 & $\begin{array}{c}0.06133 \\
0\end{array}$ & 0.137200 & $\begin{array}{c}0.00355 \\
0\end{array}$ & 833 & $\begin{array}{c}10 \\
3\end{array}$ & 838 & $\begin{array}{l}2 \\
7\end{array}$ & 829 & $\begin{array}{l}2 \\
0\end{array}$ & $98 \%$ & 0.05 \\
\hline $\begin{array}{c}1403- \\
12\end{array}$ & 0.067490 & $\begin{array}{c}0.00379 \\
0\end{array}$ & 1.281600 & $\begin{array}{c}0.07151 \\
0\end{array}$ & 0.136250 & $\begin{array}{c}0.00398 \\
0\end{array}$ & 853 & $\begin{array}{c}12 \\
0\end{array}$ & 838 & $\begin{array}{l}3 \\
2\end{array}$ & 823 & $\begin{array}{l}2 \\
3\end{array}$ & $98 \%$ & 0.23 \\
\hline $\begin{array}{c}1403- \\
13\end{array}$ & 0.069100 & $\begin{array}{c}0.00291 \\
0\end{array}$ & 1.331060 & $\begin{array}{c}0.05784 \\
0\end{array}$ & 0.138100 & $\begin{array}{c}0.00443 \\
0\end{array}$ & 902 & 89 & 859 & $\begin{array}{l}2 \\
5\end{array}$ & 834 & $\begin{array}{l}2 \\
5\end{array}$ & $96 \%$ & 0.12 \\
\hline $\begin{array}{c}1403- \\
14\end{array}$ & 0.067310 & $\begin{array}{c}0.00287 \\
0\end{array}$ & 1.289490 & $\begin{array}{c}0.05486 \\
0\end{array}$ & 0.136940 & $\begin{array}{c}0.00410 \\
0\end{array}$ & 847 & 91 & 841 & $\begin{array}{l}2 \\
4\end{array}$ & 827 & $\begin{array}{l}2 \\
3\end{array}$ & $98 \%$ & 0.10 \\
\hline $\begin{array}{c}1403- \\
15\end{array}$ & 0.071780 & $\begin{array}{c}0.00315 \\
0\end{array}$ & 1.362270 & $\begin{array}{c}0.06041 \\
0\end{array}$ & 0.137590 & $\begin{array}{c}0.00394 \\
0\end{array}$ & 980 & 92 & 873 & $\begin{array}{l}2 \\
6\end{array}$ & 831 & $\begin{array}{l}2 \\
2\end{array}$ & $95 \%$ & 0.14 \\
\hline $\begin{array}{c}1403- \\
16\end{array}$ & 0.067260 & $\begin{array}{c}0.00376 \\
0\end{array}$ & 1.288130 & $\begin{array}{c}0.06947 \\
0\end{array}$ & 0.137630 & $\begin{array}{c}0.00411 \\
0\end{array}$ & 846 & $\begin{array}{c}11 \\
9\end{array}$ & 840 & $\begin{array}{l}3 \\
1\end{array}$ & 831 & $\begin{array}{l}2 \\
3\end{array}$ & $98 \%$ & 0.13 \\
\hline $\begin{array}{c}1403- \\
17\end{array}$ & 0.067700 & $\begin{array}{c}0.00432 \\
0\end{array}$ & 1.298600 & $\begin{array}{c}0.07225 \\
0\end{array}$ & 0.138830 & $\begin{array}{c}0.00552 \\
0\end{array}$ & 859 & $\begin{array}{c}13 \\
6\end{array}$ & 845 & $\begin{array}{l}3 \\
2\end{array}$ & 838 & $\begin{array}{l}3 \\
1\end{array}$ & $99 \%$ & 0.26 \\
\hline $\begin{array}{c}1403- \\
18\end{array}$ & 0.066130 & $\begin{array}{c}0.00269 \\
0\end{array}$ & 1.280030 & $\begin{array}{c}0.06139 \\
0\end{array}$ & 0.136630 & $\begin{array}{c}0.00441 \\
0\end{array}$ & 811 & 87 & 837 & $\begin{array}{l}2 \\
7\end{array}$ & 826 & $\begin{array}{l}2 \\
5\end{array}$ & $98 \%$ & 0.09 \\
\hline $\begin{array}{c}1403- \\
19\end{array}$ & 0.068080 & $\begin{array}{c}0.00310 \\
0\end{array}$ & 1.317510 & $\begin{array}{c}0.06638 \\
0\end{array}$ & 0.137140 & $\begin{array}{c}0.00387 \\
0\end{array}$ & 871 & 97 & 853 & $\begin{array}{l}2 \\
9\end{array}$ & 828 & $\begin{array}{l}2 \\
2\end{array}$ & $97 \%$ & 0.07 \\
\hline $\begin{array}{c}1403- \\
20\end{array}$ & 0.067920 & $\begin{array}{c}0.00320 \\
0\end{array}$ & 1.305320 & $\begin{array}{c}0.06168 \\
0\end{array}$ & 0.137340 & $\begin{array}{c}0.00473 \\
0\end{array}$ & 866 & $\begin{array}{c}10 \\
0\end{array}$ & 848 & $\begin{array}{l}2 \\
7\end{array}$ & 830 & $\begin{array}{l}2 \\
7\end{array}$ & $97 \%$ & 0.35 \\
\hline $\begin{array}{c}1403- \\
21\end{array}$ & 0.075510 & $\begin{array}{c}0.00217 \\
0\end{array}$ & 1.759020 & $\begin{array}{c}0.06791 \\
0\end{array}$ & 0.166670 & $\begin{array}{c}0.00344 \\
0\end{array}$ & 1082 & 59 & 1030 & $\begin{array}{l}2 \\
5\end{array}$ & 994 & $\begin{array}{l}1 \\
9\end{array}$ & $96 \%$ & 0.29 \\
\hline $\begin{array}{c}1403- \\
22\end{array}$ & 0.066880 & $\begin{array}{c}0.00210 \\
0\end{array}$ & 1.280900 & $\begin{array}{c}0.03741 \\
0\end{array}$ & 0.138870 & $\begin{array}{c}0.00489 \\
0\end{array}$ & 834 & 67 & 837 & $\begin{array}{l}1 \\
7\end{array}$ & 838 & $\begin{array}{l}2 \\
8\end{array}$ & $99 \%$ & 0.38 \\
\hline $\begin{array}{c}1403- \\
23\end{array}$ & 0.064280 & $\begin{array}{c}0.00123 \\
0\end{array}$ & 1.228120 & $\begin{array}{c}0.02578 \\
0\end{array}$ & 0.138060 & $\begin{array}{c}0.00182 \\
0\end{array}$ & 751 & 41 & 813 & $\begin{array}{l}1 \\
2\end{array}$ & 834 & $\begin{array}{l}1 \\
0\end{array}$ & $97 \%$ & 0.16 \\
\hline $\begin{array}{c}1403- \\
24\end{array}$ & 0.066260 & $\begin{array}{c}0.00124 \\
0\end{array}$ & 1.264570 & $\begin{array}{c}0.02497 \\
0\end{array}$ & 0.137730 & $\begin{array}{c}0.00143 \\
0\end{array}$ & 814 & 40 & 830 & $\begin{array}{l}1 \\
1\end{array}$ & 832 & 8 & $99 \%$ & 0.16 \\
\hline $\begin{array}{c}1403- \\
25\end{array}$ & 0.064920 & $\begin{array}{c}0.00113 \\
0\end{array}$ & 1.234900 & $\begin{array}{c}0.02308 \\
0\end{array}$ & 0.137450 & $\begin{array}{c}0.00157 \\
0\end{array}$ & 772 & 37 & 817 & $\begin{array}{l}1 \\
0\end{array}$ & 830 & 9 & $98 \%$ & 0.28 \\
\hline $\begin{array}{c}1403- \\
26\end{array}$ & 0.066510 & $\begin{array}{c}0.00157 \\
0\end{array}$ & 1.263570 & $\begin{array}{c}0.03267 \\
0\end{array}$ & 0.136920 & $\begin{array}{c}0.00216 \\
0\end{array}$ & 823 & 50 & 830 & $\begin{array}{l}1 \\
5\end{array}$ & 827 & $\begin{array}{l}1 \\
2\end{array}$ & $99 \%$ & 0.40 \\
\hline $\begin{array}{c}1403- \\
27\end{array}$ & 0.065110 & $\begin{array}{c}0.00115 \\
0\end{array}$ & 1.235710 & $\begin{array}{c}0.02398 \\
0\end{array}$ & 0.137220 & $\begin{array}{c}0.00177 \\
0\end{array}$ & 778 & 38 & 817 & $\begin{array}{l}1 \\
1\end{array}$ & 829 & $\begin{array}{l}1 \\
0\end{array}$ & $98 \%$ & 0.27 \\
\hline $\begin{array}{c}1403- \\
28\end{array}$ & 0.068180 & $\begin{array}{c}0.00124 \\
0\end{array}$ & 1.297320 & $\begin{array}{c}0.02711 \\
0\end{array}$ & 0.137290 & $\begin{array}{c}0.00183 \\
0\end{array}$ & 874 & 38 & 845 & $\begin{array}{l}1 \\
2\end{array}$ & 829 & $\begin{array}{l}1 \\
0\end{array}$ & $98 \%$ & 0.17 \\
\hline $\begin{array}{c}1403- \\
29\end{array}$ & 0.066420 & $\begin{array}{c}0.00139 \\
0\end{array}$ & 1.260180 & $\begin{array}{c}0.02649 \\
0\end{array}$ & 0.137220 & $\begin{array}{c}0.00174 \\
0\end{array}$ & 820 & 45 & 828 & $\begin{array}{l}1 \\
2\end{array}$ & 829 & $\begin{array}{l}1 \\
0\end{array}$ & $99 \%$ & 0.35 \\
\hline $\begin{array}{c}1403- \\
30\end{array}$ & 0.066360 & $\begin{array}{c}0.00140 \\
0\end{array}$ & 1.263390 & $\begin{array}{c}0.03091 \\
0\end{array}$ & 0.137100 & $\begin{array}{c}0.00212 \\
0\end{array}$ & 818 & 45 & 829 & $\begin{array}{l}1 \\
4\end{array}$ & 828 & $\begin{array}{l}1 \\
2\end{array}$ & $99 \%$ & 0.13 \\
\hline $\begin{array}{c}1403- \\
32\end{array}$ & 0.081160 & $\begin{array}{c}0.00173 \\
0\end{array}$ & 2.164630 & $\begin{array}{c}0.06578 \\
0\end{array}$ & 0.190400 & $\begin{array}{c}0.00386 \\
0\end{array}$ & 1225 & 43 & 1170 & $\begin{array}{l}2 \\
1\end{array}$ & 1124 & $\begin{array}{l}2 \\
1\end{array}$ & $95 \%$ & 0.09 \\
\hline $\begin{array}{c}1403- \\
33\end{array}$ & 0.065520 & $\begin{array}{c}0.00112 \\
0\end{array}$ & 1.251830 & $\begin{array}{c}0.02261 \\
0\end{array}$ & 0.137720 & $\begin{array}{c}0.00141 \\
0\end{array}$ & 791 & 37 & 824 & $\begin{array}{l}1 \\
0\end{array}$ & 832 & 8 & $99 \%$ & 0.20 \\
\hline $\begin{array}{c}1403- \\
34\end{array}$ & 0.067610 & $\begin{array}{c}0.00164 \\
0\end{array}$ & 1.291380 & $\begin{array}{c}0.03148 \\
0\end{array}$ & 0.138000 & $\begin{array}{c}0.00200 \\
0\end{array}$ & 857 & 52 & 842 & $\begin{array}{l}1 \\
4\end{array}$ & 833 & $\begin{array}{l}1 \\
1\end{array}$ & $98 \%$ & 0.63 \\
\hline $\begin{array}{l}1403- \\
35\end{array}$ & 0.066110 & $\begin{array}{c}0.00187 \\
0\end{array}$ & 1.252750 & $\begin{array}{c}0.03496 \\
0\end{array}$ & 0.136620 & $\begin{array}{c}0.00229 \\
0\end{array}$ & 810 & 61 & 825 & $\begin{array}{l}1 \\
6\end{array}$ & 826 & $\begin{array}{l}1 \\
3\end{array}$ & $99 \%$ & 0.16 \\
\hline $\begin{array}{c}1403- \\
36\end{array}$ & 0.082480 & $\begin{array}{c}0.00111 \\
0\end{array}$ & 1.993340 & $\begin{array}{c}0.03110 \\
0\end{array}$ & 0.173880 & $\begin{array}{c}0.00179 \\
0\end{array}$ & 1257 & 27 & 1113 & $\begin{array}{l}1 \\
1\end{array}$ & 1033 & $\begin{array}{l}1 \\
0\end{array}$ & $92 \%$ & 0.21 \\
\hline $\begin{array}{c}1403- \\
38\end{array}$ & 0.066920 & $\begin{array}{c}0.00118 \\
0\end{array}$ & 1.276980 & $\begin{array}{c}0.02320 \\
0\end{array}$ & 0.137420 & $\begin{array}{c}0.00139 \\
0\end{array}$ & 835 & 38 & 836 & $\begin{array}{l}1 \\
0\end{array}$ & 830 & 8 & $99 \%$ & 0.20 \\
\hline $\begin{array}{c}1403- \\
39\end{array}$ & 0.067410 & $\begin{array}{c}0.00133 \\
0\end{array}$ & 1.284140 & $\begin{array}{c}0.02711 \\
0\end{array}$ & 0.137860 & $\begin{array}{c}0.00190 \\
0\end{array}$ & 850 & 42 & 839 & $\begin{array}{l}1 \\
2\end{array}$ & 833 & $\begin{array}{l}1 \\
1\end{array}$ & $99 \%$ & 0.24 \\
\hline $\begin{array}{c}1403- \\
40\end{array}$ & 0.066030 & $\begin{array}{c}0.00123 \\
0\end{array}$ & 1.266980 & $\begin{array}{c}0.02943 \\
0\end{array}$ & 0.137720 & $\begin{array}{c}0.00193 \\
0\end{array}$ & 807 & 40 & 831 & $\begin{array}{l}1 \\
3\end{array}$ & 832 & $\begin{array}{l}1 \\
1\end{array}$ & $99 \%$ & 0.21 \\
\hline
\end{tabular}




\begin{tabular}{|c|c|c|c|c|c|c|c|c|c|c|c|c|c|c|}
\hline \multicolumn{15}{|c|}{ Sample B13 (2024) } \\
\hline 2024-1 & 0.065500 & $\begin{array}{c}0.00182 \\
0\end{array}$ & 1.261080 & $\begin{array}{c}0.03157 \\
0\end{array}$ & 0.137580 & $\begin{array}{c}0.00202 \\
0\end{array}$ & 790 & 60 & 828 & $\begin{array}{l}1 \\
4\end{array}$ & 831 & $\begin{array}{l}1 \\
1\end{array}$ & $99 \%$ & 0.76 \\
\hline 2024-3 & 0.065550 & $\begin{array}{c}0.00151 \\
0\end{array}$ & 1.261460 & $\begin{array}{c}0.02696 \\
0\end{array}$ & 0.137480 & $\begin{array}{c}0.00177 \\
0\end{array}$ & 792 & 49 & 829 & $\begin{array}{l}1 \\
2\end{array}$ & 830 & $\begin{array}{l}1 \\
0\end{array}$ & $99 \%$ & 0.67 \\
\hline 2024-4 & 0.073800 & $\begin{array}{c}0.00226 \\
0\end{array}$ & 1.639830 & $\begin{array}{c}0.07227 \\
0\end{array}$ & 0.157100 & $\begin{array}{c}0.00430 \\
0\end{array}$ & 1036 & 63 & 986 & $\begin{array}{l}2 \\
8\end{array}$ & 941 & $\begin{array}{l}2 \\
4\end{array}$ & $95 \%$ & 0.43 \\
\hline $2024-5$ & 0.065770 & $\begin{array}{c}0.00171 \\
0\end{array}$ & 1.267560 & $\begin{array}{c}0.03172 \\
0\end{array}$ & 0.137710 & $\begin{array}{c}0.00168 \\
0\end{array}$ & 799 & 56 & 831 & $\begin{array}{l}1 \\
4\end{array}$ & 832 & $\begin{array}{l}1 \\
0\end{array}$ & $99 \%$ & 0.17 \\
\hline $2024-6$ & 0.065610 & $\begin{array}{c}0.00151 \\
0\end{array}$ & 1.259910 & $\begin{array}{c}0.02870 \\
0\end{array}$ & 0.137160 & $\begin{array}{c}0.00160 \\
0\end{array}$ & 794 & 49 & 828 & $\begin{array}{l}1 \\
3\end{array}$ & 829 & 9 & $99 \%$ & 0.10 \\
\hline 2024-7 & 0.192840 & $\begin{array}{c}0.00375 \\
0\end{array}$ & 14.152860 & $\begin{array}{c}0.27214 \\
0\end{array}$ & 0.524830 & $\begin{array}{c}0.00644 \\
0\end{array}$ & 2767 & 33 & 2760 & $\begin{array}{l}1 \\
8\end{array}$ & 2720 & $\begin{array}{l}2 \\
7\end{array}$ & $98 \%$ & 0.58 \\
\hline 2024-8 & 0.125120 & $\begin{array}{c}0.00292 \\
0\end{array}$ & 6.523570 & $\begin{array}{c}0.25613 \\
0\end{array}$ & 0.369490 & $\begin{array}{c}0.01122 \\
0\end{array}$ & 2031 & 42 & 2049 & $\begin{array}{l}3 \\
5\end{array}$ & 2027 & $\begin{array}{l}5 \\
3 \\
\end{array}$ & $98 \%$ & 0.15 \\
\hline 2024-9 & 0.066640 & $\begin{array}{c}0.00242 \\
0\end{array}$ & 1.262060 & $\begin{array}{c}0.03383 \\
0\end{array}$ & 0.136860 & $\begin{array}{c}0.00302 \\
0\end{array}$ & 826 & 78 & 829 & $\begin{array}{l}1 \\
5\end{array}$ & 827 & $\begin{array}{l}1 \\
7\end{array}$ & $99 \%$ & 0.95 \\
\hline $\begin{array}{c}2024- \\
10\end{array}$ & 0.064080 & $\begin{array}{c}0.00244 \\
0\end{array}$ & 1.226520 & $\begin{array}{c}0.04888 \\
0\end{array}$ & 0.137390 & $\begin{array}{c}0.00252 \\
0\end{array}$ & 744 & 82 & 813 & $\begin{array}{l}2 \\
2\end{array}$ & 830 & $\begin{array}{l}1 \\
4\end{array}$ & $97 \%$ & 0.52 \\
\hline $\begin{array}{c}2024- \\
11\end{array}$ & 0.066140 & $\begin{array}{c}0.00188 \\
0\end{array}$ & 1.265900 & $\begin{array}{c}0.03624 \\
0\end{array}$ & 0.137420 & $\begin{array}{c}0.00196 \\
0\end{array}$ & 811 & 61 & 831 & $\begin{array}{l}1 \\
6\end{array}$ & 830 & $\begin{array}{l}1 \\
1\end{array}$ & $99 \%$ & 0.75 \\
\hline $\begin{array}{c}2024- \\
12\end{array}$ & 0.065710 & $\begin{array}{c}0.00168 \\
0\end{array}$ & 1.256240 & $\begin{array}{c}0.03288 \\
0\end{array}$ & 0.137210 & $\begin{array}{c}0.00176 \\
0\end{array}$ & 797 & 55 & 826 & $\begin{array}{l}1 \\
5\end{array}$ & 829 & $\begin{array}{l}1 \\
0\end{array}$ & $99 \%$ & 0.34 \\
\hline $\begin{array}{c}2024- \\
13\end{array}$ & 0.065450 & $\begin{array}{c}0.00201 \\
0\end{array}$ & 1.244370 & $\begin{array}{c}0.04078 \\
0\end{array}$ & 0.137260 & $\begin{array}{c}0.00311 \\
0\end{array}$ & 789 & 66 & 821 & $\begin{array}{l}1 \\
8\end{array}$ & 829 & $\begin{array}{l}1 \\
8\end{array}$ & $98 \%$ & 0.23 \\
\hline $\begin{array}{c}2024- \\
14\end{array}$ & 0.091810 & $\begin{array}{c}0.00181 \\
0\end{array}$ & 3.232250 & $\begin{array}{c}0.09501 \\
0\end{array}$ & 0.251450 & $\begin{array}{c}0.00549 \\
0\end{array}$ & 1463 & 38 & 1465 & $\begin{array}{l}2 \\
3\end{array}$ & 1446 & $\begin{array}{l}2 \\
8\end{array}$ & $98 \%$ & 0.51 \\
\hline $\begin{array}{c}2024- \\
15\end{array}$ & 0.187020 & $\begin{array}{c}0.00318 \\
0\end{array}$ & 13.625470 & $\begin{array}{c}0.26920 \\
0\end{array}$ & 0.522990 & $\begin{array}{c}0.00715 \\
0\end{array}$ & 2716 & 29 & 2724 & $\begin{array}{l}1 \\
9\end{array}$ & 2712 & $\begin{array}{l}3 \\
0\end{array}$ & $99 \%$ & 0.50 \\
\hline $\begin{array}{c}2024- \\
16\end{array}$ & 0.065920 & $\begin{array}{c}0.00125 \\
0\end{array}$ & 1.258770 & $\begin{array}{c}0.02696 \\
0\end{array}$ & 0.137290 & $\begin{array}{c}0.00196 \\
0\end{array}$ & 804 & 41 & 827 & $\begin{array}{l}1 \\
2\end{array}$ & 829 & $\begin{array}{l}1 \\
1\end{array}$ & $99 \%$ & 0.08 \\
\hline $\begin{array}{c}2024- \\
17\end{array}$ & 0.066710 & $\begin{array}{c}0.00166 \\
0\end{array}$ & 1.268090 & $\begin{array}{c}0.03102 \\
0\end{array}$ & 0.137130 & $\begin{array}{c}0.00173 \\
0\end{array}$ & 829 & 53 & 832 & $\begin{array}{l}1 \\
4\end{array}$ & 828 & $\begin{array}{l}1 \\
0\end{array}$ & $99 \%$ & 1.35 \\
\hline $\begin{array}{c}2024- \\
18\end{array}$ & 0.067360 & $\begin{array}{c}0.00143 \\
0\end{array}$ & 1.282690 & $\begin{array}{c}0.03134 \\
0\end{array}$ & 0.137190 & $\begin{array}{c}0.00202 \\
0\end{array}$ & 849 & 45 & 838 & $\begin{array}{l}1 \\
4\end{array}$ & 829 & $\begin{array}{l}1 \\
1\end{array}$ & $98 \%$ & 0.57 \\
\hline $\begin{array}{c}2024- \\
19\end{array}$ & 0.064720 & $\begin{array}{c}0.00149 \\
0\end{array}$ & 1.233740 & $\begin{array}{c}0.02989 \\
0\end{array}$ & 0.137480 & $\begin{array}{c}0.00196 \\
0\end{array}$ & 765 & 50 & 816 & $\begin{array}{l}1 \\
4\end{array}$ & 830 & $\begin{array}{l}1 \\
1\end{array}$ & $98 \%$ & 0.12 \\
\hline $\begin{array}{c}2024- \\
20\end{array}$ & 0.065460 & $\begin{array}{c}0.00363 \\
0\end{array}$ & 1.233810 & $\begin{array}{c}0.06695 \\
0\end{array}$ & 0.137320 & $\begin{array}{c}0.00412 \\
0\end{array}$ & 789 & $\begin{array}{c}12 \\
0\end{array}$ & 816 & $\begin{array}{l}3 \\
0\end{array}$ & 829 & $\begin{array}{l}2 \\
3\end{array}$ & $98 \%$ & 0.51 \\
\hline $\begin{array}{c}2024- \\
21\end{array}$ & 0.066630 & $\begin{array}{c}0.00173 \\
0\end{array}$ & 1.265260 & $\begin{array}{c}0.03105 \\
0\end{array}$ & 0.137180 & $\begin{array}{c}0.00189 \\
0\end{array}$ & 826 & 56 & 830 & $\begin{array}{l}1 \\
4\end{array}$ & 829 & $\begin{array}{l}1 \\
1\end{array}$ & $99 \%$ & 0.05 \\
\hline $\begin{array}{c}2024- \\
22\end{array}$ & 0.074260 & $\begin{array}{c}0.00150 \\
0\end{array}$ & 1.810960 & $\begin{array}{c}0.04373 \\
0\end{array}$ & 0.175420 & $\begin{array}{c}0.00257 \\
0\end{array}$ & 1049 & 42 & 1049 & $\begin{array}{l}1 \\
6\end{array}$ & 1042 & $\begin{array}{l}1 \\
4\end{array}$ & $99 \%$ & 0.55 \\
\hline $\begin{array}{c}2024- \\
23\end{array}$ & 0.066190 & $\begin{array}{c}0.00159 \\
0\end{array}$ & 1.261210 & $\begin{array}{c}0.03078 \\
0\end{array}$ & 0.137450 & $\begin{array}{c}0.00190 \\
0\end{array}$ & 812 & 51 & 828 & $\begin{array}{l}1 \\
4\end{array}$ & 830 & $\begin{array}{l}1 \\
1\end{array}$ & $99 \%$ & 0.30 \\
\hline $\begin{array}{c}2024- \\
24\end{array}$ & 0.067000 & $\begin{array}{c}0.00123 \\
0\end{array}$ & 1.272010 & $\begin{array}{c}0.02652 \\
0\end{array}$ & 0.137150 & $\begin{array}{c}0.00216 \\
0\end{array}$ & 838 & 39 & 833 & $\begin{array}{l}1 \\
2\end{array}$ & 829 & $\begin{array}{l}1 \\
2\end{array}$ & $99 \%$ & 0.25 \\
\hline $\begin{array}{c}2024- \\
25\end{array}$ & 0.102110 & $\begin{array}{c}0.00180 \\
0\end{array}$ & 3.584060 & $\begin{array}{c}0.07952 \\
0\end{array}$ & 0.252520 & $\begin{array}{c}0.00385 \\
0\end{array}$ & 1663 & 33 & 1546 & $\begin{array}{l}1 \\
8\end{array}$ & 1451 & $\begin{array}{l}2 \\
0\end{array}$ & $93 \%$ & 0.37 \\
\hline $\begin{array}{c}2024- \\
26\end{array}$ & 0.064560 & $\begin{array}{c}0.00148 \\
0\end{array}$ & 1.226440 & $\begin{array}{c}0.02806 \\
0\end{array}$ & 0.137150 & $\begin{array}{c}0.00155 \\
0\end{array}$ & 760 & 50 & 813 & $\begin{array}{l}1 \\
3\end{array}$ & 829 & 9 & $98 \%$ & 0.27 \\
\hline $\begin{array}{c}2024- \\
27\end{array}$ & 0.067460 & $\begin{array}{c}0.00150 \\
0\end{array}$ & 1.278110 & $\begin{array}{c}0.02780 \\
0\end{array}$ & 0.137070 & $\begin{array}{c}0.00156 \\
0\end{array}$ & 852 & 47 & 836 & $\begin{array}{l}1 \\
2\end{array}$ & 828 & 9 & $99 \%$ & 0.99 \\
\hline $\begin{array}{c}2024- \\
28\end{array}$ & 0.091880 & $\begin{array}{c}0.00183 \\
0\end{array}$ & 3.249860 & $\begin{array}{c}0.10258 \\
0\end{array}$ & 0.249300 & $\begin{array}{c}0.00547 \\
0\end{array}$ & 1465 & 39 & 1469 & $\begin{array}{l}2 \\
5\end{array}$ & 1435 & $\begin{array}{l}2 \\
8\end{array}$ & $97 \%$ & 0.30 \\
\hline $\begin{array}{c}2024- \\
29\end{array}$ & 0.066310 & $\begin{array}{c}0.00183 \\
0\end{array}$ & 1.262900 & $\begin{array}{c}0.03063 \\
0\end{array}$ & 0.137480 & $\begin{array}{c}0.00249 \\
0\end{array}$ & 816 & 59 & 829 & $\begin{array}{l}1 \\
4\end{array}$ & 830 & $\begin{array}{l}1 \\
4\end{array}$ & $99 \%$ & 0.16 \\
\hline $\begin{array}{c}2024- \\
30\end{array}$ & 0.103270 & $\begin{array}{c}0.00206 \\
0\end{array}$ & 4.121880 & $\begin{array}{c}0.09396 \\
0\end{array}$ & 0.287030 & $\begin{array}{c}0.00418 \\
0\end{array}$ & 1684 & 38 & 1659 & $\begin{array}{l}1 \\
9\end{array}$ & 1627 & $\begin{array}{l}2 \\
1\end{array}$ & $98 \%$ & 0.38 \\
\hline $\begin{array}{c}2024- \\
32\end{array}$ & 0.165130 & $\begin{array}{c}0.00275 \\
0\end{array}$ & 9.749940 & $\begin{array}{c}0.16470 \\
0\end{array}$ & 0.425100 & $\begin{array}{c}0.00489 \\
0\end{array}$ & 2509 & 29 & 2411 & $\begin{array}{l}1 \\
6\end{array}$ & 2284 & $\begin{array}{l}2 \\
2\end{array}$ & $94 \%$ & 0.27 \\
\hline $\begin{array}{c}2024- \\
34\end{array}$ & 0.087950 & $\begin{array}{c}0.00142 \\
0\end{array}$ & 2.597700 & $\begin{array}{c}0.04192 \\
0\end{array}$ & 0.213070 & $\begin{array}{c}0.00222 \\
0\end{array}$ & 1381 & 32 & 1300 & $\begin{array}{l}1 \\
2\end{array}$ & 1245 & $\begin{array}{l}1 \\
2\end{array}$ & $95 \%$ & 0.61 \\
\hline $\begin{array}{c}2024- \\
35\end{array}$ & 0.067390 & $\begin{array}{c}0.00193 \\
0\end{array}$ & 1.332540 & $\begin{array}{c}0.03908 \\
0\end{array}$ & 0.142400 & $\begin{array}{c}0.00157 \\
0\end{array}$ & 850 & 61 & 860 & $\begin{array}{l}1 \\
7\end{array}$ & 858 & 9 & $99 \%$ & 0.32 \\
\hline $\begin{array}{c}2024- \\
36\end{array}$ & 0.073230 & $\begin{array}{c}0.00192 \\
0\end{array}$ & 1.663310 & $\begin{array}{c}0.04593 \\
0\end{array}$ & 0.163620 & $\begin{array}{c}0.00209 \\
0\end{array}$ & 1020 & 54 & 995 & $\begin{array}{l}1 \\
8\end{array}$ & 977 & $\begin{array}{l}1 \\
2\end{array}$ & $98 \%$ & 0.13 \\
\hline $\begin{array}{c}2024- \\
37\end{array}$ & 0.073210 & $\begin{array}{c}0.00114 \\
0\end{array}$ & 1.704990 & $\begin{array}{c}0.03831 \\
0\end{array}$ & 0.167600 & $\begin{array}{c}0.00301 \\
0\end{array}$ & 1020 & 32 & 1010 & $\begin{array}{l}1 \\
4\end{array}$ & 999 & $\begin{array}{l}1 \\
7\end{array}$ & $98 \%$ & 0.74 \\
\hline $\begin{array}{c}2024- \\
38\end{array}$ & 0.070540 & $\begin{array}{c}0.00167 \\
0\end{array}$ & 1.341650 & $\begin{array}{c}0.03098 \\
0\end{array}$ & 0.137440 & $\begin{array}{c}0.00165 \\
0\end{array}$ & 944 & 50 & 864 & $\begin{array}{l}1 \\
3\end{array}$ & 830 & 9 & $96 \%$ & 0.35 \\
\hline $\begin{array}{c}2024- \\
39\end{array}$ & 0.066290 & $\begin{array}{c}0.00143 \\
0\end{array}$ & 1.262510 & $\begin{array}{c}0.02869 \\
0\end{array}$ & 0.137480 & $\begin{array}{c}0.00186 \\
0\end{array}$ & 816 & 46 & 829 & $\begin{array}{l}1 \\
3\end{array}$ & 830 & $\begin{array}{l}1 \\
1\end{array}$ & $99 \%$ & 0.48 \\
\hline $\begin{array}{c}2024- \\
40\end{array}$ & 0.069440 & $\begin{array}{c}0.00155 \\
0\end{array}$ & 1.318220 & $\begin{array}{c}0.03404 \\
0\end{array}$ & 0.136960 & $\begin{array}{c}0.00275 \\
0\end{array}$ & 912 & 47 & 854 & $\begin{array}{l}1 \\
5\end{array}$ & 827 & $\begin{array}{l}1 \\
6\end{array}$ & $96 \%$ & 0.37 \\
\hline
\end{tabular}




\begin{tabular}{|c|c|c|c|c|c|c|c|c|c|c|c|c|}
\hline Sample & $176 \mathrm{Yb} / 177 \mathrm{Hf}$ & $2 \sigma$ & $176 \mathrm{Lu} / 177 \mathrm{Hf}$ & $2 \sigma$ & $176 \mathrm{Hf} / 177 \mathrm{Hf}$ & $2 \sigma$ & $\varepsilon H f(t)$ & $\varepsilon H f(0)$ & $\operatorname{Age}(M a)$ & $T D M 1(M a)$ & $T D M 2(M a)$ & $f(L u / H f)$ \\
\hline \multicolumn{13}{|c|}{ Sample A37 (1403) } \\
\hline 1403-01.xls & 0.069465 & 0.001329 & 0.002551 & 0.000049 & 0.282182 & 0.000018 & -4.26 & -20.85 & 815 & 1573 & 1977 & -0.92 \\
\hline 1403-02.xls & 0.033276 & 0.002444 & 0.001317 & 0.000096 & 0.282133 & 0.000017 & -5.35 & -22.59 & 814 & 1591 & 2046 & -0.96 \\
\hline 1403-03.xls & 0.052056 & 0.000445 & 0.001897 & 0.000020 & 0.282240 & 0.000019 & -1.89 & -18.82 & 814 & 1464 & 1828 & -0.94 \\
\hline 1403-05.xls & 0.020281 & 0.000170 & 0.000823 & 0.000008 & 0.282080 & 0.000013 & -6.79 & -24.48 & 823 & 1645 & 2143 & -0.98 \\
\hline 1403-07.xls & 0.061695 & 0.001249 & 0.002307 & 0.000047 & 0.282159 & 0.000038 & -4.69 & -21.68 & 828 & 1597 & 2014 & -0.93 \\
\hline 1403-10.xls & 0.035740 & 0.000612 & 0.001399 & 0.000023 & 0.282159 & 0.000012 & -4.33 & -21.68 & 821 & 1558 & 1987 & -0.96 \\
\hline 1403-11.xls & 0.015152 & 0.000361 & 0.000611 & 0.000014 & 0.282152 & 0.000011 & -3.99 & -21.94 & 829 & 1536 & 1971 & -0.98 \\
\hline 1403-12.xls & 0.032853 & 0.000245 & 0.001274 & 0.000009 & 0.282167 & 0.000014 & -3.95 & -21.40 & 823 & 1542 & 1964 & -0.96 \\
\hline 1403-13.xls & 0.060701 & 0.001586 & 0.002274 & 0.000052 & 0.282210 & 0.000017 & -2.74 & -19.88 & 834 & 1522 & 1896 & -0.93 \\
\hline 1403-14.xls & 0.033084 & 0.001351 & 0.001302 & 0.000052 & 0.282124 & 0.000017 & -5.39 & -22.92 & 827 & 1603 & 2058 & -0.96 \\
\hline 1403-16.xls & 0.031782 & 0.000622 & 0.001255 & 0.000024 & 0.282096 & 0.000014 & -6.26 & -23.89 & 831 & 1640 & 2116 & -0.96 \\
\hline 1403-17.xls & 0.034896 & 0.000528 & 0.001431 & 0.000019 & 0.282118 & 0.000016 & -5.43 & -23.12 & 838 & 1617 & 2069 & -0.96 \\
\hline 1403-18.xls & 0.018821 & 0.001017 & 0.000813 & 0.000046 & 0.281955 & 0.000025 & -11.15 & -28.91 & 826 & 1817 & 2418 & -0.98 \\
\hline 1403-19.xls & 0.069655 & 0.001338 & 0.002645 & 0.000045 & 0.282206 & 0.000014 & -3.22 & -20.03 & 828 & 1544 & 1922 & -0.92 \\
\hline 1403-20.xls & 0.043510 & 0.000604 & 0.001756 & 0.000024 & 0.282195 & 0.000019 & -3.07 & -20.41 & 830 & 1522 & 1914 & -0.95 \\
\hline 1403-22.xls & 0.028666 & 0.000751 & 0.001136 & 0.000029 & 0.282155 & 0.000015 & -3.96 & -21.81 & 838 & 1553 & 1976 & -0.97 \\
\hline 1403-23.xls & 0.060435 & 0.001617 & 0.002269 & 0.000057 & 0.282119 & 0.000015 & -5.96 & -23.10 & 834 & 1653 & 2099 & -0.93 \\
\hline 1403-24.xls & 0.040540 & 0.001049 & 0.001561 & 0.000038 & 0.282197 & 0.000024 & -2.84 & -20.33 & 832 & 1511 & 1901 & -0.95 \\
\hline 1403-26.xls & 0.033645 & 0.000740 & 0.001340 & 0.000028 & 0.282199 & 0.000015 & -2.74 & -20.25 & 827 & 1499 & 1891 & -0.96 \\
\hline
\end{tabular}




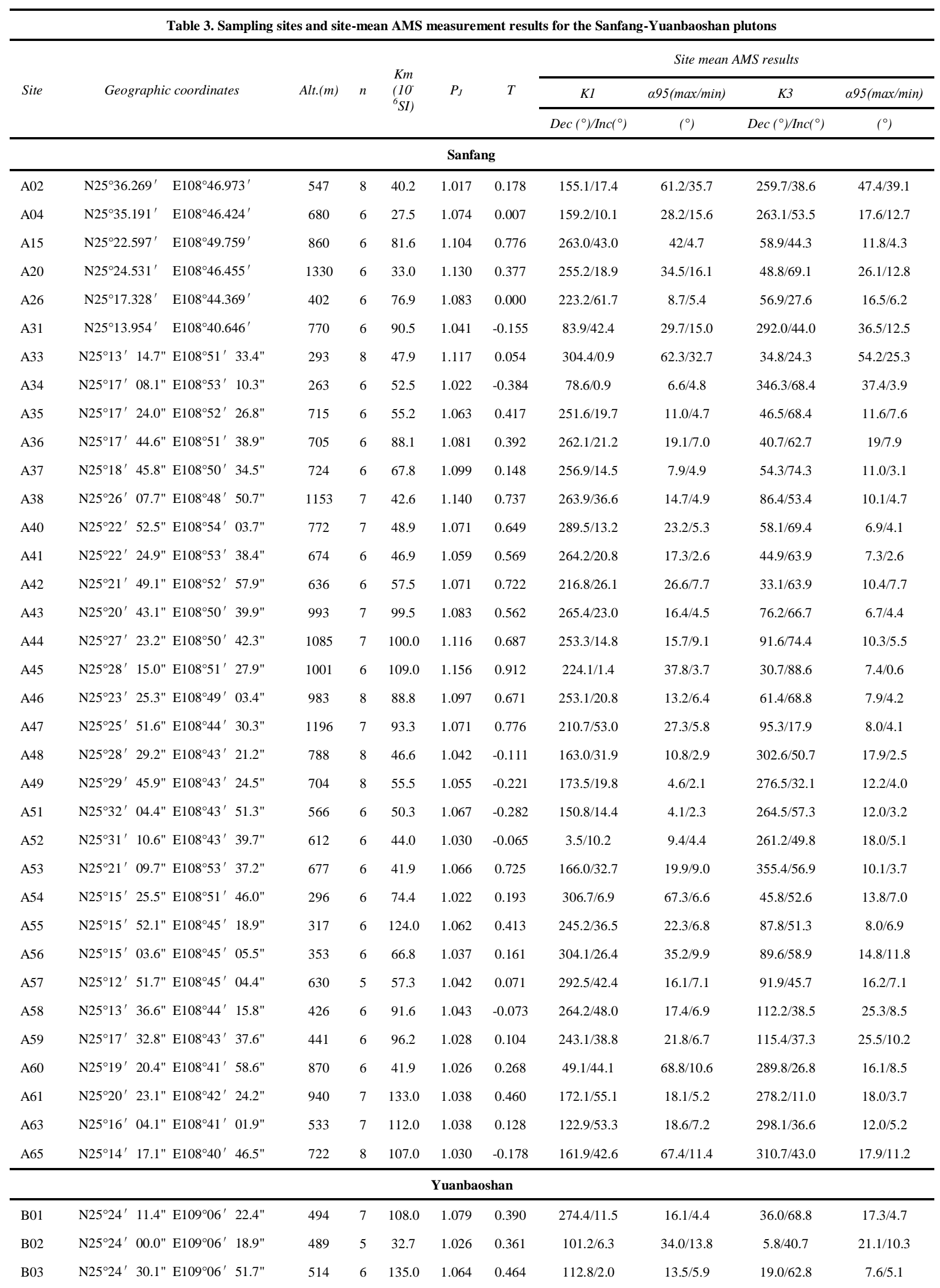




\begin{tabular}{|c|c|c|c|c|c|c|c|c|c|c|c|c|c|}
\hline B04 & $\mathrm{N} 25^{\circ} 25^{\prime}$ & $09.4 "$ & $\mathrm{E} 109^{\circ} 07^{\prime}$ & 23.8 & 575 & 5 & 108.0 & 1.068 & 0.083 & $313.5 / 1.3$ & $42.4 / 6.4$ & $220.9 / 64.0$ & $38.8 / 4.0$ \\
\hline B05 & $\mathrm{N} 25^{\circ} 25^{\prime}$ & $43.0^{\prime \prime}$ & $\mathrm{E} 109^{\circ} 08^{\prime}$ & 29.0 & 715 & 6 & 76.4 & 1.128 & 0.643 & $128.1 / 2.6$ & $32.4 / 3.7$ & $249.7 / 85.0$ & $20.5 / 3.8$ \\
\hline B06 & $\mathrm{N} 25^{\circ} 26^{\prime}$ & $11.6 "$ & $\mathrm{E} 109^{\circ} 08^{\prime}$ & 24.6 & 828 & 6 & 172.0 & 1.041 & 0.479 & $148.5 / 4.1$ & $26.7 / 4.3$ & $326.5 / 85.9$ & $10.7 / 4.3$ \\
\hline B07 & $\mathrm{N} 25^{\circ} 27^{\prime}$ & $34.9^{\prime \prime}$ & $\mathrm{E} 109^{\circ} 09^{\prime}$ & 56.5 & 986 & 7 & 112.0 & 1.150 & 0.775 & $318.9 / 2.9$ & $15.4 / 1.6$ & $71.1 / 82.3$ & $3.7 / 1.5$ \\
\hline B08 & $\mathrm{N} 25^{\circ} 28^{\prime}$ & 18.0" & $\mathrm{E} 109^{\circ} 10^{\prime}$ & 32.0 & 802 & 6 & 197.0 & 1.168 & 0.817 & $336.0 / 3.2$ & $24.0 / 9.5$ & $114.9 / 85.7$ & $10.9 / 3.7$ \\
\hline B09 & $\mathrm{N} 25^{\circ} 28^{\prime}$ & $47.3^{\prime \prime}$ & $\mathrm{E} 109^{\circ} 10^{\prime}$ & 47.6 & 622 & 6 & 82.9 & 1.078 & -0.149 & $167.6 / 6.9$ & $7.8 / 5.4$ & $34.0 / 80.1$ & $16.4 / 6.2$ \\
\hline B10 & $\mathrm{N} 25^{\circ} 29^{\prime}$ & $41.9^{\prime \prime}$ & $\mathrm{E} 109^{\circ} 12^{\prime}$ & 03.7 & 332 & 6 & 74.2 & 1.102 & -0.384 & $333.0 / 7.4$ & 7.3/1.7 & $71.6 / 48.7$ & $22.7 / 6.8$ \\
\hline B11 & $\mathrm{N} 25^{\circ} 15^{\prime}$ & $13.7^{\prime \prime}$ & $\mathrm{E} 109^{\circ} 10^{\prime}$ & 29.8 & 173 & 6 & 79.7 & 1.009 & 0.166 & $255.3 / 58.8$ & $58.1 / 18.9$ & $159.5 / 3.2$ & $46.7 / 18.8$ \\
\hline B12 & $\mathrm{N} 25^{\circ} 17^{\prime}$ & $24.2^{\prime \prime}$ & $\mathrm{E} 109^{\circ} 11^{\prime}$ & 45.9 & 202 & 8 & 167.0 & 1.016 & -0.094 & $165.0 / 17.7$ & $27.5 / 18.6$ & $282.4 / 55.3$ & $43.4 / 18.5$ \\
\hline B13 & $\mathrm{N} 25^{\circ} 18^{\prime}$ & $06.9^{\prime \prime}$ & $\mathrm{E} 109^{\circ} 11^{\prime}$ & $52.2 "$ & 222 & 6 & 152.0 & 1.023 & -0.325 & $155.9 / 23.4$ & $16.9 / 12.4$ & $262.5 / 33.4$ & $48.7 / 15.3$ \\
\hline B14 & $\mathrm{N} 25^{\circ} 19^{\prime}$ & $08.4 "$ & $\mathrm{E} 109^{\circ} 11^{\prime}$ & $46.9 "$ & 234 & 6 & 135.0 & 1.034 & -0.305 & $155.4 / 24.6$ & $13 / 3.4$ & $8.9 / 61.3$ & $31.6 / 10.5$ \\
\hline B15 & $\mathrm{N} 25^{\circ} 20^{\prime}$ & $35.0^{\prime \prime}$ & $\mathrm{E} 109^{\circ} 12^{\prime}$ & 26.6 & 315 & 6 & 74.0 & 1.026 & -0.094 & $165.5 / 12.6$ & $14.0 / 3$ & $258.8 / 14.4$ & $26.7 / 6.8$ \\
\hline B16 & $\mathrm{N} 25^{\circ} 21^{\prime}$ & $03.0^{\prime \prime}$ & $\mathrm{E} 109^{\circ} 11^{\prime}$ & 38.0 & 523 & 5 & 85.9 & 1.038 & 0.534 & $181.2 / 30.4$ & $19.7 / 11.8$ & $70.5 / 31.1$ & $21.4 / 6.6$ \\
\hline B17 & $\mathrm{N} 25^{\circ} 21^{\prime}$ & $46.0^{\prime \prime}$ & $\mathrm{E} 109^{\circ} 10^{\prime}$ & $43.3 "$ & 837 & 8 & 76.3 & 1.056 & 0.127 & $182 / 28.5$ & $26.1 / 6.5$ & $78.5 / 23.2$ & $33.7 / 6.8$ \\
\hline B18 & $\mathrm{N} 25^{\circ} 16^{\prime}$ & $45.0^{\prime \prime}$ & $\mathrm{E} 109^{\circ} 12^{\prime}$ & 38.5 & 175 & 6 & 83.6 & 1.022 & -0.265 & $131.6 / 8.3$ & $14.8 / 5.7$ & $38.1 / 22.9$ & $18.8 / 13.9$ \\
\hline B19 & $\mathrm{N} 25^{\circ} 18^{\prime}$ & $12.6^{\prime \prime}$ & $\mathrm{E} 109^{\circ} 13^{\prime}$ & 29.7 & 329 & 7 & 63.0 & 1.028 & -0.235 & $184.9 / 27.2$ & $18.1 / 5.7$ & $42.5 / 57$ & $8.8 / 4.8$ \\
\hline B20 & $\mathrm{N} 25^{\circ} 25^{\prime}$ & $02.7 "$ & $\mathrm{E} 109^{\circ} 12^{\prime}$ & 54.6 & 785 & 6 & 79.3 & 1.172 & 0.636 & $269.7 / 36.4$ & $10.5 / 4.1$ & $94.4 / 53.5$ & $5.9 / 1.2$ \\
\hline
\end{tabular}

Note: Alt.: Altitude, n: number of specimen at sampling site, Km: bulk magnetic susceptibility PJ: degree of susceptibility anisotropy, T: shape parameter of the AMS ellipsoid, K1: Magnetic lineation, K3: The pole of the magnetic foliation, Inc.: Inclination, Dec.: Declination, $\alpha 95$ (max/min): the long and short axes of the confidence ellipsoid at $95 \%$ level 


\begin{tabular}{|c|c|c|c|c|c|}
\hline Strata/Rock & Lithology & $\begin{array}{c}\text { Sampling } \\
\text { number }\end{array}$ & $\begin{array}{l}\text { Density of each } \\
\text { sample }\left(\mathrm{g} / \mathrm{cm}^{3}\right)\end{array}$ & $\begin{array}{c}\text { Average of measured } \\
\text { density }(\mathrm{g} / \mathrm{cm} 3)\end{array}$ & $\begin{array}{c}\text { Standard } \\
\text { derivation }\end{array}$ \\
\hline \multirow{21}{*}{$\gamma 2$ Sanfang } & \multirow{21}{*}{ Granite } & 1404 & 2.630 & \multirow{21}{*}{2.606} & \multirow{21}{*}{0.0425} \\
\hline & & A35 & 2.534 & & \\
\hline & & A37 & 2.586 & & \\
\hline & & A38 & 2.601 & & \\
\hline & & A39 & 2.663 & & \\
\hline & & $\mathrm{A} 40$ & 2.549 & & \\
\hline & & A42 & 2.559 & & \\
\hline & & $\mathrm{A} 45$ & 2.670 & & \\
\hline & & A46 & 2.671 & & \\
\hline & & A 48 & 2.592 & & \\
\hline & & A49 & 2.615 & & \\
\hline & & A51 & 2.591 & & \\
\hline & & A52 & 2.622 & & \\
\hline & & A55 & 2.673 & & \\
\hline & & A57 & 2.576 & & \\
\hline & & A58 & 2.648 & & \\
\hline & & A59 & 2.534 & & \\
\hline & & A62 & 2.582 & & \\
\hline & & $\mathrm{A} 63$ & 2.631 & & \\
\hline & & A65 & 2.602 & & \\
\hline & & A66 & 2.587 & & \\
\hline \multirow{6}{*}{$\gamma 2$ Yuanbaoshan } & \multirow{6}{*}{ Granite } & B07 & 2.597 & \multirow{6}{*}{2.606} & \multirow{6}{*}{0.0129} \\
\hline & & B09 & 2.594 & & \\
\hline & & B02 & 2.621 & & \\
\hline & & B05 & 2.623 & & \\
\hline & & B19 & 2.591 & & \\
\hline & & B20 & 2.612 & & \\
\hline \multirow{13}{*}{ Sibao Group } & Slate & 1406 & 2.741 & \multirow{13}{*}{2.678} & \multirow{13}{*}{0.0577} \\
\hline & Slate & 1415 & 2.673 & & \\
\hline & Slate & 1419 & 2.664 & & \\
\hline & Slate & 1422 & 2.757 & & \\
\hline & Slate & 1425 & 2.740 & & \\
\hline & Sandstone & 1427 & 2.648 & & \\
\hline & Sandstone & 1429 & 2.684 & & \\
\hline & Slate & 1439 & 2.706 & & \\
\hline & Slate & 1447 & 2.679 & & \\
\hline & Slate & 1451 & 2.622 & & \\
\hline & Sandstone & 1453 & 2.763 & & \\
\hline & Sandstone & 1458 & 2.568 & & \\
\hline & Slate & 1459 & 2.763 & & \\
\hline
\end{tabular}




\begin{tabular}{|c|c|c|c|c|c|}
\hline & Slate & 1460 & 2.681 & & \\
\hline & Slate & $1468 \mathrm{a}$ & 2.692 & & \\
\hline & Slate & 1469 & 2.754 & & \\
\hline & Slate & 2002 & 2.696 & & \\
\hline & Slate & 2003 & 2.601 & & \\
\hline & Sandstone & 2004 & 2.671 & & \\
\hline & Sandstone & 2006 & 2.545 & & \\
\hline & Sandstone & 2007 & 2.655 & & \\
\hline & Sandstone & 2020 & 2.628 & & \\
\hline & Slate & 2031 & 2.678 & & \\
\hline & Slate & 2051 & 2.584 & & \\
\hline & Slate & 2052 & 2.700 & & \\
\hline & Slate & 2054 & 2.722 & & \\
\hline & Slate & 2055 & 2.685 & & \\
\hline \multirow{7}{*}{ Danzhou Group } & Sandstone & 1420 & 2.756 & \multirow{7}{*}{2.686} & \multirow{7}{*}{0.0851} \\
\hline & Sandstone & 1461 & 2.734 & & \\
\hline & Sandstone & $2000-1$ & 2.528 & & \\
\hline & Sandstone & 2001 & 2.738 & & \\
\hline & Sandstone & 2064 & 2.704 & & \\
\hline & Blastopsammite & 2066 & 2.585 & & \\
\hline & Sandstone & 2067 & 2.759 & & \\
\hline \multirow{3}{*}{ Sinian } & \multirow{3}{*}{ Sandstone } & 2040 & 2.715 & \multirow{3}{*}{2.710} & \multirow{3}{*}{0.0066} \\
\hline & & $2040-1$ & 2.714 & & \\
\hline & & $2040-2$ & 2.701 & & \\
\hline
\end{tabular}

